\title{
AMPHIBIANS AND REPTILES OF THE MCELMO RARE LIZARD AND SNAKE AREA IN SOUTHWEST COLORADO
}

\author{
R. Bruce Bury \\ U.S. Fish and Wildlife Service \\ National Fish and Wildlife Laboratory \\ 3825 E. Mulberry \\ Fort Collins, CO 80521
}

37 p. and 17 Figures

A report to the Bureau of Land Management, Montrose, Colorado 81401 


\section{BLM Library}

Denver Federal Center

Bldg. 50, OC-521

P.O. Box 25047

Denver, CO 80225

Author: R. Bruce Bury
USGS, BRD

Forest \& Range Land Ecosystem

Science Center

3200 S.W. Jefferson Way

Corvallis, OR 97331

cuser, 200 i 


\section{INTRODUCTION}

Surveys of the herpetology of Colorado are provided by Maslin (1959) and Smith et al. (1965). These latter authors stated that the knowledge of the distribution of Colorado herpetozoa was not yet sufficiently detailed for a definitive analysis of zoogeographic correlations. Much still remains to be discovered about the geographic distribution and ecology of Colorado's reptiles and amphibians.

The western slope of the Rocky Mountains has a rich herpetofauna (Table 1), including several desert forms (Table 2). These forms have arrived in recent dispersals eastward in the valleys of major river systems (McC, oy 1966). The western tier of counties in Colorado is the limital range for 19 species: three toads, one turtle, eight lizards, and seven snakes (Table 2).

Mesa County in west-central Colorado, and Montezuma County in the southwestern corner, and closely adjacent areas (Figure 1) are the principal areas in the state where certain species occur. The Canyon treefrog is known only from Mesa County, and from one mesa in Las Animas County. The Western spadefoot is found only in the southwestern corner of the state, while the Great Basin spadefoot occurs only in west-central Colorado. Leopard lizards and spotted night snakes frequent desert areas of Garfield, Mesa, and Montezuma Counties. The yellow-bellied racer is known only from west-central Colorado. The desert spiny lizard, lesser earless lizard, and common kingsnake occur only in Montezuma County; the rare Utah black-headed snake is only known from Mesa County. There is one locality record for western painted turtles in La Plata County, and only sight records for the coachwhip at Mesa Verde National Park, and Yellowjacket Canyon, 30 miles west of Cortez, Montezuma County (Maslin 1959).

Recent references to the herpetofauna of western Colorado are few. McCoy (1962) reported on additions to the herpetofauna of Mesa County. Douglas 
(1966) studied the fauna at Mesa Verde National Park. Unpublished reports discussing the amphibians and reptiles of Montezuma County are provided by Zortman (1968) and Somners (1974). There has been no comprehensive study of the herpetofauna of southwestern Colorado, or of the western slope region.

McCoy (1964) describes the western lowland group of amphibians and reptiles that dispersed eastward into Colorado: canyon treefrog, leopard lizard, western whiptail, plateau whiptail, yellow-bellied racer, black rat snake, spotted night snake, and Utah black-headed snake. These forma dispersed along a corridor (Colorado River) into Mesa County in west-central Colorado.

The herpetofauna of southwestern Colorado is composed of some elements typical of the western lowland fauna and western slope species. The Colorado River valley extends east through the San Juan River drainage (Figure 2). Desert and canyonland habitat occur in Montezuma County, particularly in the areas west and south of Cortez. Pinyon woodland grows above 5,000 ft. elevation in much of this area, while the few canyons and valleys at lower elevations are mostly open areas of greasewood and other arid land shrubs.

McElmo Creek runs westward from Cortez, Colorado into the San Juan River (Figure 2). The lowlands and canyonlands of the McElmo Creek area harbor the only known populations of the desert spiny lizard (Sceloporus magister) and kingsnake (Lampropeltis getulus) in Colorado. In addition, this is one of the few areas in the state where leopard lizards (Crotaphytus wislizenii) and spotted night snakes (Hypsiglena torquata) occur. The lesser earless lizard (Holbrookia maculata approximans) occurs in southwestern Colorado in desert habitat near Towaoc, 15-25 miles southwest of Cortez, in Mesa Verde National Park and possibly also elsewhere in sandy areas. Because of these reptiles and other unique features in the area, Zortman (1968) proposed part of the McElmo system as a Natural Area in Colorado.

The International Biological Programs (IBP) identified the McElmo Reptile Natural Area (Figure 3) in 1970. The Bureau of Land Management has 
established a 443-acre tract as the McElmo Rare Lizard and Snake Area (hereafter called the MLSA) (Figure 4), and has completed plant censuses of this area. (Reports available from the BLM District Office, P.O. Box 1269, Montrose, CO 81401.) The MLSA is located along part of Bridge Canyon, with the "bridge" being a rock outcrop across the valley floor inside the reserve. Descriptions of the MLSA are available elsewhere (Zortman 1968, BLM reports).

This present study was done in order to obtain a detailed inventory of the reptiles and amphibians of the MLSA. The objectives were to: 1) prepare a reptile and amphibian species list for the 443-acre tract; 2) indicate the distribution, densities, and habitat types of the herpetofauna; 3) survey the distribution of species in adjacent areas for comparison; and 4) explain the methods used, analyze the data, discuss the herpetological values, and recommend management guidelines for adequate protection of the herpetofauna.

\section{MATERIALS AND METHODS}

In order to obtain a broad knowledge of the herpetofauna, data collection was done using five different approaches.

\section{Review of Existing Data}

The geographic distribution files at the University of Colorado Museum (UCM) at Boulder were reviewed. UCM has the most extensive records of the herpetofauna in Colorado. The records for UCM specimens from Montezuma County, Colorado, and adjacent San Juan County, Utah are listed in Appendix 1. These records and pertinent literature are discussed later.

\section{Opportunistic Surveys}

An effort was made to search as much as the MLSA as possible by repeated walks through the area. All observed reptiles were recorded on field maps (Figure 5) redrawn from a 1958 U.S. Geological Survey map of Aneth 1 SE, UtahColorado (Scale 1: 24000). Elevations are given in feet. 
Identifications of lizards were made only by trained personnel. Most lizards were wary, but could be approached to distances of 1-2 $\mathrm{m}$ for close viewing. Lizards could be seen as far away as $10 \mathrm{~m}$ on either side of the traveled route. Most of the opportunistic observations were made from $0800-1200$, but we also did searches during the afternoon, and in the evening.

Several general searches for amphibians and reptiles were made in the area. Night driving of roads was done along the Pleasant Valley road (N of the MLSA), the McElmo Creek road (south of the MLSA) from 0 to 30 miles west of Cortez, and along Route 666 when traveling to or from Cortez. Daytime collecting was also done along the McElmo Creek valley, and north of the reserve. We attempted to sample a variety of habitats at different times in the vicinity of the McElmo Natural Area in order to provide comparisons to nearby areas and to thoroughly sample the local herpetofauna.

\section{Line Transects}

Eight walking line transects were conducted in lowlands or canyonlands in extreme western Montezuma County, Colorado (Figure 6). The sites were: McElmo Rare Lizard and Snake Area (MLSA) (two transects, June 18); N and NE of the MLSA (June 17); Bridge Canyon, 1.5 miles north of the MLSA boundary (July 26); McClean Basin, 8 miles NNE of the MLSA (July 29); Hovenweep Canyon, 7 miles NE of the MLSA (July 30); and Bridge Canyon, S of the MLSA boundary (August 15).

Each transect was about one mile long. All observed animals were noted along the route. The visibility on each side of the route was about $10 \mathrm{~m}$.

\section{Quadrats}

Earlier, we had developed a standardized sampling technique for use in arid habitats (Bury et al. 1977). This system was modified for use in the reserve area.

Six quadrats of 2-ha each $(100 \mathrm{~m} \times 200 \mathrm{~m})$ were established in the three principal habitats: mesa $(M)$, rocky slope $(R)$, and alluvial substrate in the valley (V) (Figure 7), with two quadrats in each habitat. We censused one quadrat per 
habitat (M1-R1-V1) in mid-June, and another set (M2-R2-V2) in late July 1977. The number and size (height and average diameter) of each plant of perennial vegetation was measured in a belt transect $10 \mathrm{~m} \times 50 \mathrm{~m}$ or $10 \mathrm{~m} \times 100 \mathrm{~m}$ inside each quadrat.

Each quadrat was systematically patrolled for one morning by one or two observers. The location of observed animals was noted on field maps, and wherever possible, animals were captured, measured, weighed, and marked (harmless toe-clip) before release at the site of capture. We also marked lizards with a black ink felt pen so that captured individuals would be recognizable, and not captured or counted again. Some animals could not be captured, so their locations and species were noted. If on a later patrol, a similiar individual was seen in the same area, we did not record it again.

\section{Pit Fall Traps}

Field studies by our laboratory's biologists in Florida have revealed that can traps are an effective means to sample herpetofaunas, particularly secretive forms. Ten can traps were installed in and near the McElmo reserve (A-E, Figure 8), and four others $(\mathrm{N1}-4)$ were placed 2.5 miles $\mathrm{N}$ of the reserve.

We used 5-gallon cans (round wastepaper baskets), buried flush with the top of the soil at all sites. Dritt fences ( $50 \mathrm{ft}$. long, made of 6 -inch high valley tin) were placed at three sites (B, C, E) in the valley floor (Figure 8). The other sites (A, D, N1-4) were in rocky terrain and the traps were buried along the edges of natural barriers (bottom of ridges or boulders). The traps were covered with flat rocks propped 1-2 inches above the lip by smaller stones. Animals fell into the pits when moving along the fences or barriers or when seeking shelter under the flat rocks. 


\section{SCHEDULE}

1977

April 19-20

Two days

(6 man-days)

Site visit with Terry Reed, BLM

R. B. Bury, R. A. Luckenbach, R. B. Finley.

June 14-18

Five days

(20 man-days)

Surveys of reserve; censuses of 3 quadrats; 4 line transects; general searches; mammal trapping; 4 can traps set.

July 20-23

Four days

(8 man-days)

July 24-August 4

Twelve days

(12 man-days)

R. B. Bury, R. A. Luckenbach, M. Killpack, M. Armstrong.

Census of 1 quadrat; general surveys; 14 pit fall traps installed.

R. B. Bury and C. J. McCoy.

Census of 2 quadrats; 3 line transects; pit fall census; general surveys.

C. J. McCoy

August 13-17

Five days

1 line transect; pit fall census; general search

(12 man-days)

August 20-22

Two days

(2 man-days)

R. B. Bury, H. W. Campbell, N. J. Scott (2).

Pit fall census: remove traps

R. B. Bury

Total $=30$ days $(60$ man-days $)$ of field time 


\section{PARTICIPANTS}

Dr. R. Bruce Bury, Project Leader, is a Zoologist with the National Fish and Wildlife Laboratory (NFWL) located at the Fort Collins Field Station, Colorado. His specialty is non-game wildlife, especially herpetology.

Dr. Howard Campbell and Dr. Norman Scott are National Fish and Wildlife Laboratory Zoologists; both did their graduate work in herpetology. Dr. Campbell is at the NFWL Gainesville Station, Florida, and Dr. Scott is stationed in Albuquerque, New Mexico.

$$
i i j
$$

Dr. Clarence J. McCoy served as a consultant because of his experience in western Colorado. He is the Curator of Herpetology, Carnegie Museum, Pittsburgh, PA.

Dr. Robert B. Finley, Jr. is Mammologist and Chief of the Fort Collins Field Station, National Fish and Wildlife Laboratory.

Roger A. Luckenbach is a NFWL biologist (intermittent) and assists the research program of $\mathrm{Dr}$. Bury. Mr. Luckenbach is a $\mathrm{PhD}$ candidate at the University of California, Berkeley.

Mike Armstrong and Merlin Killpack are seasonal biologists with the Fort Collins Field Station. 


\section{RESULTS AND DISCUSSION}

\section{Review of Existing Data}

The review of existing literature (Maslin 1959, Smith et al. 1965, Zortman 1968, Somners 1974, and Spencer 1974) and UCM records (Appendix 1) enabled us to compile a list of the reptiles and amphibians previously found or thought to occur in the MLSA and adjacent areas. This was used as a checklist with which to compare our findings (see Herpetofaunal Analysis). This review revealed that no substantive surveys of reptiles and amphibians had ever been done on the MLSA or Bridge Canyon.

\section{Opportunistic Surveys}

We searched all parts of the MLSA during opportunistic surveys (Figure 9). The distributions of lizards seen during these surveys are shown in Figures 10-16. A total of 219 sightings of lizards (7 species) were made: 68 Sceloporus undulatus, 57 Uta stansburiana, 55 Cnemidophorus tigris, 20 Crotaphytus collaris, 9 Sceloporus magister, 9 Urosaurus ornatus, and 1 Crotaphytus wislizenii. One bullsnake (Pituophis melanoleucus) was found basking in the sun among rocks at the south side of the bridge (near can traps $D$ ). This snake was an adult male, measuring $1.5 \mathrm{~m}$ in total length. No amphibians were found on these surveys.

Collecting was done in the area outside the MLSA (see Field Notes) and records of these animals are discussed later (see Herpetological Analysis). No snakes were found during night driving because most of the roads driven were unpaved. Snakes prefer pavement to unsurfaced roads, and are easier to observe on pavement. A few snakes were found dead on roads (DOR) during the daytime. Live amphibians were found on dirt and paved roads at night during and after rainstorms.

\section{Line Transects}

We found 97 lizards ( 6 species) along our 8 line transects (Table 3). The average number seen was 12.1 (2-38) lizards per mile. Most of the areas traversed were canyonlands or streambeds. 
Low species diversity and low numbers of individuals were noted at three localities (B, C, F). Sites B and C were searched on days that were hot and dry (no recent rains); lizard activity might have been reduced under these conditions. Site $F$ is at an elevation of about $6000 \mathrm{ft}$., whereas the other sites are all lower (5000 -5400 ft.). Site F may be unfavorable for local lizards.

High diversities and numbers of lizards were found north ( $A$ and $E$ ), south (H), and within the MLSA (D), all along Bridge Canyon (Table 3). Apparently, the vegetation and flats adjacent to this wash are favorable habitat to many lizards. The most abundant and diverse lizard populations occurred along a stretch of the wash S of the MLSA, where the streambed sides have high dirt walls and some rocks. Tamarisk grows in some areas and nearby vegetation is relatively dense. In this area, we also uncovered one red-spotted toad (Bufo punctatus) under a large rock. The toad was probably on the surface because heavy rains fell prior to the time this transect was walked.

We saw 35 C. tigris, 23 Sceloporus undulatus, 18 S. magister, and 8 Crotaphytus collaris using the line transect technique. The only $S$. graciosus was seen 7 miles NE of the MLSA. Few Uta and no Urosaurus were observed.

\section{Quadrats}

The quadrat sampling technique revealed that the vegetation of the six quadrats were markedly different from one another (Table 4). Mesa sights were covered principally with a Sarcobates-Atriplex plant community (M1) or Artemisia-Eurotia with some Atriplex and Cowania (M2). Valley sites contained Atriplex with some Sarcobates (V1), or pure stands of Sarcobates (V2). In contrast, the rocky slope sites had a variety of perennials, including small trees (Fraxinus, Cercocarpus, and Juniperus). Site R1 had a large proportion of Atriplex, whereas R2 contained mostly Eurotia and Chrysothamnus. The rocky slopes are complex habitats with varied terrain, cliff faces, and large structural differences in vegetation (low perennials, shrubs, trees) (see Field Notes for June 17, 1977).

We captured 77 lizards ( 6 species) on the six quadrats (Table 5): 35 C. tigris 


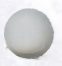

. 
(30 Ad:5 Juv), 19 Uta (13 Ad:6 Juv), 7 Urosaurus (6 Ad:1 Juv), 7 Crotaphytus collaris (Ads), 6 Sceloporus undulates (Ads), and 3 Crotaphytus wislizenii (Ads)

One $C$. wislizenii was found on each of the habitat types (M2, V1, R1). These were the only leopard lizards observed inside the MLSA.

\section{Pit Fall Trapping}

The series of ten pit fall traps (A-E) in or close to the MLSA captured 60 individuals (6 species) (Table 6): 46 C tigris, 6 Sceloporus undulatus, $5 \mathrm{~S}$. magister, and one each of three amphibians (Scaphiopus hammondi, Bufo punctatus, Ambystoma tigrinum). The pit fall traps were the only method that yielded records of amphibians within the MLSA.

Pit fall traps were effective in catching C. tigris (77\% of the total sample), which is a ground-dwelling lizard. Four $C$. tigris were each recaptured once, one was recaptured twice. One adult $S$. magister was recaptured once.

The catch taken in different traps varied. Trap sets $B$ and $C$ were in the open valley floor, and in both sets 9 C. tigris were taken. Trap set $A$ had cans buried at the base of a cliff; $3 \mathrm{~S}$. magister and $10 \mathrm{C}$. tigris were obtained there. In the lower valley, set $\mathrm{D}$ along the south base of the bridge captured $8 \mathrm{C}$. tigris, $6 \mathrm{~S}$. undulatus, and 1 Ambystoma tigrinum. Set $\mathrm{E}$ near the stream channel netted the most animals: 10 C tigris, $2 \mathrm{~S}$. magister, 1 Scaphiopus, and 1 Bufo woodhousei.

Four traps (N set) located 2.5 miles $\mathrm{N}$ of the MLSA yielded only two animals: 1 Bufo punctatus (July 24) and 1 Crotaphytus collaris (August 14).

\section{Comparisons of Approaches}

The five types of methods used in this study all revealed different aspects of the herpetofauna of the MLSA. Each one provided types of information not contributed by the others.

The review of existing data provided baseline data for the general area and a checklist with which to compare our results. This approach was useful in providing information on the habitats and distribution of the species in the area. Thus we could avoid unnecessary duplication of the efforts of others, and place our study in the historical perspective. 
Our walking surveys in the MLSA yielded the most sightings and number of species of any approach used (Table 7). Many lizards were observed. The general occurrence of the species in the MLSA was related to the major habitats (mesas, rocky slopes, valleys) (Figures 10-16). The mesa lizard fauna is depauperate. Rocky slopes and the canyon rims harbor a rich lizard fauna, especially Sceloporus undulatus, Urosaurus, Uta, and Crotaphytus collaris. We found no snakes in the deep fissures and rock talus slopes of the canyon sides, but they appear favorable for snakes. There is an adequate food supply of lizards and small rodents (see Field Notes for June 15-17, 1977) to support a healthy snake fauna in the rocky slopes of the MLSA. The valley floor has an abundant population of whiptails (C. tigris). Dirt walls, exposed bedrock, and vegetation of the streambed are occupied by Sceloporus magister, S. unduilatus, and Crotaphytus collaris. Almost all of the $S$. magister were observed in the wash.

Line transects provided additional sightings but few species. One Sceloporus graciosus and one Bufo punctatus were found. Line transect revealed that populations of $S$. magister also occurred N and NE of the MLSA in Bridge Canyon. On transects further $\mathrm{n}$ and NE of the MLSA, no S. magister or Crotaphytus wislizenii were seen. The line transects gave a generalized assessment of herpetofauna, but seem to have limited scope since secretive species were rarely observed.

The quadrat searches involved a large investment of time per lizard recorded (2.2/man-hour), but the repeated patrols clearly showed that the lizard fauna of rocky slope areas was 2.3 to 2.5 times greater than that found in valley sites, and 2.3 to 5 times greater than in mesa habitats (Table 5). The intense searches of quadrats yielded all of the sightings of leopard lizards (Crotaphytus wislizenii) in the MLSA. Further, this approach provided evidence indicating that Urosaurus ornatus and Crotaphytus collaris are most abundant in rocky habitats.

Pit fall traps took a lot of time to install, but little time to check. This technique provided the fewest number of individuals, but the only records for three species of amphibians in the MLSA (Table 7). No snakes were captured in 
the traps, but longer periods of trapping and a different array (12-24 traps) would increase the chances of capturing snakes. Other studies indicate that pit fall traps are one of the best methods for discovering secretive species like most snakes.

This comparison shows that the four sampling techniques employed here reveal different numbers of individuals and species in a herpetofauna (Table 7). They also provide differing estimates of species composition in varying habitats. By using a combination of these methods, we achieved a comprehensive picture of the reptiles and amphibians present in the McElmo Rare Lizard and Snake Area vicinity.

\section{Herpetofaunal Analysis}

The species collected or observed in this field inventory at, or adjacent to the MLSA and those reported by Zortman (1968) in the general area are given in Table 8. The following comments are provided to clarify the distributional records and to briefly discuss the abundance and habitats of the herpetofauna of the McElmo Rare Lizard and Snake Area.

Ambystoma tigrinum utahensis, Utah tiger salamander

Maslin (1959) reported a specimen from near Towaoc, 5 miles S of Cortez. Other recent localities are known near Cortez and in San Juan Co., Utah (UCM specimens).

We found one immature individual in can trap D (Figure 8), at the cliff base between the bridge and the valley floor. This salamander was dead in the trap (one of the few casualties); the specimen was preserved. The animal apparently was active following heavy rainstorms on August 15-16. This specimen represents the first record for the species from the MLSA and the lower McElmo Creek area.

The abundance of tiger salamanders in the MLSA is unknown. They probably occur at temporary pools in the valleys following rainstorms. 
Scaphiopus hammondi, western spadefoot toad

Maslin (1959) reported specimens from near Cortez.

We found $S$. hammondi at several new localities in western Montezuma Co. On July 22, C. J. McCoy and I found these toads abundant from 0 to 5.5 miles $\mathrm{W}$ of Cortez along the road next to McElmo Creek. We took 14 adults and sub-adults. Many more were observed on the road. H. W. Campbell, N. J. Scott, and I collected a series of $S$. hammondi tadpoles from 8.9 miles $W$ of Cortez (August 15) and 0.4 miles $S$ of Pleasant Valley Road ( 0.6 miles $E$ Utah-Colorado line) (August 17). On August 17, N. J. Scott observed a chorus singing in a stock pond 2 miles NNE of the MLSA. One adult was taken on Pleasant Valley Road, 0.6 miles E of the Utah-Colorado line.

Immediately adjacent to the MLSA, one adult $S$. hamtmondi was captured on August 17 in can trap set E, next to the wash in the lower valley. It was taken as a voucher specimen.

Spadefoot toads have a disjunct distribution. They probably are uncommon in the MLSA due to the lack of standing water. One small pool was noted in the lower valley about $200 \mathrm{~m} \mathrm{~W}$ of trap set $\mathrm{E}$, but no amphibians were found here. S. hammondi frequents areas with sandy soils, such as alluvial bottomland.

Bufo punctatus, red-spotted toad

Maslin (1959) reported the species from McElmo Creek, near McElmo Creek, 3 miles W and 3 miles $S$ of Yellow Jacket (Reed Ranch), and 30 miles W of Cortez at the mouth of Yellowjacket Canyon.

We collected this toad from pit fall trap set " $N$ " ( 2.5 miles $N$ of the MLSA) (1 specimen, July 24), and from 0.5 miles $S$ of the MLSA along Bridge Canyon near the main wash (1 specimen, August 15).

The red-spotted toad has been found both $\mathrm{N}$ and $\mathrm{S}$ of the MLSA, and this species probably will be recorded on the MLSA with further collecting. This toad occurs near temporary or permanent pools in dry areas; its distribution is 
spotty (Somners 1974). I would predict its occurrence in the valley alluvial plains in the MLSA.

Bufo woodhousei woodhousei, Rocky Mountain toad

Maslin (1959) has a specimen recorded from 30 miles W of Cortez at the mouth of Yellowjacket Canyon. He also lists four other localities in other parts of Montezuma Co.

We found Rocky Mountain toads at 0 to 5.5 miles W of Cortez ( 5 specimens taken on July 22), and one adult in pit fall trap set " $E$ " in the lower valley of the MLSA (August 4).

Bufo woodhousei occurs in a variety of habitats and likely lives throughout the canyon bottom habitat in the MLSA. It is probably common during favorable periods of moisture and rainstorms.

Rana pipiens, leopard frog

Maslin (1959) reported the frog from 30 miles W of Cortez at the mouth of Yellowjacket Canyon, and McElmo Creek, 5 miles W of Cortez. Zortman (1968) listed the frog as associated with the MLSA.

Leopard frogs are aquatic species and require permanent water. There are no such conditions present in the MLSA, except watering holes that are sometimes dug in the wash for use by sheep. We found no leopard frogs in the MLSA. They may occur nearby in flowing water (Yellowjacket Canyon) or in stock ponds.

Cnemidophorus tigris septentrionalis, western whiptail lizard

Maslin (1959) has records from 30 miles W of Cortez at the mouth of Yellowjacket Canyon, and from five other localities in Montezuma Co. In Colorado, C. tigris live in a variety of ecological situations below $6000 \mathrm{ft}$. in the valleys of major river systems (McCoy 1966).

The preferred habitat in Colorado is pure stands of Sarcobates and pinyonjuniper woodlands on sandy soils (McCoy 1966). C. tigris was one of the most abundant lizards in the MLSA. It was the most common lizard on the 
valley floor, and apparently the only lizard of any numbers on the mesa tops where few lizards occurred.

Cnemidophorus velox, plateau whiptail lizard

Maslin (1959) reported the species from 3 miles S and 3 miles W of Yellow Jacket (18 miles NW of the MLSA), McElmo Creek ( 5 miles W of Cortez), Mesa Verde National Park, and three localities near Towaoc ( $\mathrm{S}$ of Cortez).

C. velox is found most abundantly at the lower elevations where pinyonjuniper forest mingles with some other stand type such as chaparral, grassland, or other woodland (Somners 1974). The species reproduces by parthenogenesis, i.e. the population is entirely made up of females.

We found $C$. velox at 1.6 miles NE of the Ismay Trading Post, which is at the mouth of Yellowjacket Canyon. The mouth of Bridge Canyon is nearby. Both $C$. tigris and $C$. velox were observed along the flood plain of Yellowjacket Creek in sandy soils with tamarisk bushes. Three specimens of each species were taken from there on August 15, representing the first $C$. velox found in W Montezuma Co.

Zortman (1968) does not include $C$. velox among the vertebrates associated with the MLSA. We do not know how far $C$. velox extends up Bridge Canyon from Yellowjacket Canyon, but there are no physical barriers against its dispersal. The lives of sympatric $C$. tigris and $C$. velox merit further study, as both are similar in size and may be competitors for common resources.

We tentatively include $C$. velox as part of the Bridge Canyon herpetofauna.

Crotaphytus collaris auriceps, yellow-headed collared lizard

Maslin (1959) reported specimens from 30 miles W of Cortez at the mouth of Yellowjacket Canyon, 3 miles S and 3 miles W of Yellow Jacket, and at seven other localities in Montezuma Co. A recent specimen (UCM 32271) is from Yellow Jacket. 
We collected $C$. collaris at Bridge Canyon (2 specimens, July 27-28), Hovenweep Canyon ( 1 specimen, July 30; about 6 miles NE of the MLSA), Bridge Canyon ( 3 specimens, July 31), 0.1 miles $S$ of Holly House (2.5 miles N of the MLSA; 1 specimen, August 14), and 0.7 miles NE of Ismay Trading Post (1 specimen, August 15). We also observed $C$. collaris at many localities in the area (see Filed Notes).

C. collaris was abundant in the canyon slope habitat and occasionally seen in the valley and mesa areas where there were basking and territorial perches (rocks, ledges, stumps). C. collaris is a predator on small lizards and large insects. This is a striking lizard with a greenish body and a sulfur-colored head.

\section{Crotaphytus wislizenii, leopard lizard}

Maslin (1959) reported the species from 0.5 miles $\mathrm{E}$ and 0.25 miles $\mathrm{N}$ of Four Corners, Four Corners (SW San Juan River), and 21 miles SW of Towaoc. Zortman (1968) listed C. wislizenii as a rare lizard in the MLSA.

One specimen was taken at Bridge Canyon just N of the MLSA (July 2728). We observed adult leopard lizards in three habitats $(M 2, V 1, R 1)$ inside of the MLSA. On June 17, a small adult male was found near the top of the canyon rim (5160 ft.) The lizard was basking at the base of a rock outcrop on reddish soil, and attempted to escape into a nearby juniper tree. We captured the animal with a noose. The snout-vent length was $97 \mathrm{~mm}$, and the tail was $205 \mathrm{~mm}$ long; its weight was $30 \mathrm{~g}$. On June 18, we found this lizard again, $50 \mathrm{~m} \mathrm{~W}$ of the location of its first capture. Two $C$. wislizenii were also observed. On June 16 , one adult was in a bush about $25 \mathrm{~m} \mathrm{~N}$ of the bridge; this lizard escaped from us. One adult was seen basking on a rock on the NW corner of quadrat M2 (mesa habitat) on July 25.

Large insects and small lizards comprised the majority of the food of $C$. wislizenii studied in Mesa, Co., Colorado (McCoy 1967). On northern study areas (Great Basin Desert), leopard lizards consume primarily grasshoppers, 
beetles, and small vertebrates (primarily other lizards), in order of volumetric importance (Parker and Pianka 1976).

Parker and Pianka (1976) stated that $C$. wislizenii is an essentially flatland desert form, while $C$. collaris is primarily a rock-dweller. McCoy (1967) found $C$. wislizenis in Mesa Co., Colorado to occur in sandy or clay soils with greasewood, sagebrush, and saltbush associations. On the basis of its ecology and distribution elsewhere, $C$. wislizenii should occur in the valley areas of Bridge Canyon. The few available observations indicate that $C$. wislizenii frequents rocky areas and the mesa tops near Bridge Canyon.

Sceloporus graciosus, sagebrush lizard

Maslin (1959) reported that $S$. graciosus occurs 30 miles W of Cortez at the mouth of Yellowjacket Canyon, Yellow Jacket, 5 miles W of Cortez (McElmo Creek), and at 11 other localities in Montezuma Co. There are 17 localities for UCM specimens in Montezuma Co. (Appendix 1).

One specimen was taken in Hovenweep Canyon, 7 miles NE of the MLSA (July 30). None were located in the MLSA during our surveys.

Zortman (1968) listed S. graciosus as associated with the MLSA. The species occurs at higher elevations and in sagebrush habitat, which is not typical of the MLSA. At present, there is no record of S. graciosus known for the MLSA.

Sceloporus undulatus, eastern fence lizard

Maslin (1959) listed the species from 13 localities in Montezuma Co. We collected specimens from Bridge Canyon (3 specimens, July 27-28), McClean Basin (1 specimen, July 29), and Bridge Canyon (3 specimens, July 31). The species was observed throughout the area.

S. undulatus occupies a wide variety of habitats (Somners 1974). Most of the lizards we observed in the MLSA occurred on rocky slopes, boulders, and along the sides of the main wash. S. undulatus was the most frequently observed lizard in the MLSA. 
Sceloporus magister, desert spiny lizard

Maslin (1959) reported the species from 30 miles W of Cortez at the mouth of Yellowjacket Canyon (13 specimens), and three other localities in the SW corner of Montezuma Co. Zortman (1968) listed S. magister as a rare lizard in the MLSA. Somners (1974) found it to be most abundant in flat washes that had some willows and other shrubs in the Yellowjacket Canyon. $S$. magister only occurs in this part of Colorado, and westward into Utah and other states.

We collected the species at Bridge Canyon (3 specimens, July 25) north of the MLSA. Several were observed in the MLSA in wash habitat, to which this species appears to be restricted. We only found $S$. magister at elevation below $5500 \mathrm{ft}$. The stream channel seems to be critical habitat for the species in Colorado.

We also observed $S$. magister along the stream channel $S$ of the MLSA and at McElmo Creek, 0.2 miles E of the Ismay Trading Post (August 16). In addition, two UCM localities are of note: Yellowjacket Canyon near the Utah line (43325-26), and Yellowjacket Canyon (43327). Apparently, Colorado $S$. magister are found only in the Yellowjacket-Bridge Canyon area and along McElmo Creek valley near the Ismay Trading Post.

The habits of this lizard differ over its range. In some areas, lizards seem to prefer rocks or boulders. Elsewhere, the lizard is arboreal or ground dwelling. In Utah, adult $S$. magister were found to be primarily arboreal on cottonwood, mesquite, and willow, but some individuals frequented large boulders (Tinkle 1976). S. magister in Bridge Canyon appear to occupy the sides of the streambed. In such habitat, the species was relatively common.

Urosaurus ornatus, tree lizard

Maslin (1959) recorded specimens from 30 miles W of Cortez at the mouth of Yellowjacket Canyon, 3 miles S and 3 miles W of Yellowjacket, and at three other localities in Montezuma Co. 
We collected four specimens from Bridge Canyon (July 27 and July 31), north of the MLSA. Inside the MLSA, our surveys revealed the species on rocks and boulders, and on sandstone ledges along the canyon rim. It was nowhere abundant.

Uta stansburiana, side-blotched lizard

A common lizard found throughout Montezuma Co. (Maslin 1959, Smith et al. 1965). We found the species in all of the habitats in the MLSA, particularly in rocky terrain. Uta was one of the most abundant lizards present.

Phrynosoma douglassi, short-horned lizard

Maslin (1959) mentions an old record from "McElmo", and records the species from Yellow Jacket and Mesa Verde national Park.

Further search may reveal the horned lizard on or near the MLSA

Holbrookia maculata, speckled earless lizard

Maslin (1959) reports its occurrence near Towaoc, S of Cortez. This lizard frequents sandy areas or grassland. The range of this species may include the McElmo-Yellowjacket Canyons. Presently, there are no records for Bridge Canyon, and its presence there is doubtful.

Crotalus viridis nuntius, Hopi rattlesnake

Maslin (1959) reported one specimen from Yellowjacket Canyon (W of Cortez) and others from near Towaoc and Mesa Verde National Park. One specimen (UCM 11855) is from 18 miles SW of Pleasant View, which is near the MLSA area.

We found one $C$. v. nuntius 14.2 miles W of Hwy. 666 on Pleasant View Road ( 1 specimen, July 22). Another DOR snake was found about 8 miles W of the Utah-Colorado line on Pleasant Valley Road, but the adult snake was badly smashed (discarded). Both snakes were located in areas with plowed fields.

The rattlesnake is likely to be found on the MLSA. The rocky cliffs are favorable habitat for $C$. viridis. 


\section{Hypsiglena torquata loreala, Mesa Verde night snake}

Maslin (1959) reports specimens from Mesa Verde National Park in Montezuma Co. Zortman (1968) listed it as present on the MLSA. There are no confirmed observations or specimens for the area.

Lampropeltis getulus, common kingsnake

Spencer (1974) reported one snake from McElmo Canyon, Montezuma Co. This is the only record of the species in Colorado. There is a possibility that L.getulus is present in the MLSA since the habitat is similar to the conditions occupied by the species further west.

Lampropeltis triangulum celaenops, New Mexico milk snake

Maslin (1959) refers to snakes taken in Mesa Verde,National Park, and to a literature report from Cortez. Recently, a specimen (UCM 27245) was added to the herpetofauna of Mesa Verde National Park.

There are no records of this species in western Montezuma Co.

Pituophis melanolecus, bullsnake

Maslin (1959) reported bullsnakes near Cortez and in the Mesa Verde National Park. Other recent specimens are from Yellow Jacket (UCM 21648) and 2 miles W and 3 miles S of Yellow Jacket (UCM 21649).

We collected one snake 1.8 miles $W$ of the Hovenweep National Monument Headquarters, and another 2 miles W (July 26 and August 2, respectively). One adult bullsnake was observed in the MLSA (July 27).

Masticophis taeniatus taeniatus, desert striped whipsnake

Maslin (1959) cites a literature record from McElmo Canyon, Montezuma Co. There are no UCM specimens for Montezuma Co. The snake probably occurs in the area.

Masticophis flagellum piceus, red racer or coachwhip

Maslin (1959) observed one snake 30 miles W of Cortez at the mouth of Yellowjacket Canyon that he believes was a M. f. piceus. There are no specimens known for the area. 
Tantilla utahensis, Utah black-headed snake

McCoy (1964) reported finding this species in Mesa Co., Colorado. The distribution of this snake is similar to those of other arid land reptiles found in Montezuma Co. There are no records of this secretive snake in SW Colorado, but further collecting with pit fall traps may reveal Tantilla.

Thamnophis elegans vagrans, wandering garter snake Maslin (1959) records this species from about 10 miles $S$ of Yellow Jacket, 11 miles NW of Cortez, and at three other localities in Montezuma Co. UCM specimens are from 20.5 miles W of Cortez on McElmo Creek (UCM $11840-41)$ and Yellow Jacket (UCM 11842).

We collected $T$. e. vagrans from 0.8 miles $\mathrm{S}$ of Arriola School on Hwy. 666 (1 specimen, July 20).

This semi-aquatic snake is associated with standing water. Its occurrence in the MLSA is doubtful.

The snake fauna at the MLSA should receive further sampling. There are possibilities of desert snakes in the reserve, such as Hypsiglena torquata, Lampropeltis getulus, Tantilla utahensis, and Masticophis. Other snakes that may eventually be found in the area include Coluber constrictor, Salvadora hexalepis, Arizona elegans, Rhinocheilus lecontei, and Thamnophis cyrtopsis.

Little can be said about the habits and habitats of the snakes of the MLSA at this stage of our knowledge.

\section{CONCLUSIONS AND RECOMMENDATIONS}

The Bridge Canyon drainage contains a varied topography and several plant communities typical of Colorado Plateau desert-shrub and pinyon-juniper. Elements of Great Basin Desert communities occur in lowland areas of major river valleys. Mesa and valley bottomland are covered with greasewood, sagebrush, saltbush, winterfat, rabbitbrush, prickly pear, and grasses. Tamarisk occurs along washes in the valleys, whereas juniper grows on parts of the mesas. Canyon rims, walls, massive boulders, and talus-like slopes constitute the sides of 
the valleys. The canyon side vegetation includes sagebrush, skunkbush, cliffrose, several species of cacti, other low perennials, and scattered trees (ash, mountain mahogany, and juniper). All of these habitats occur in the McElmo Rare Lizard and Snake Area. These habitats contrast with pinyon-juniper woodland found at higher elevations (above $5500 \mathrm{ft}$.).

About one mile S of the MLSA, Bridge Canyon meets Yellowjacket Canyon, a broad valley with a small, permanent creek. This tributary empties into McElmo Creek, which is another mile to the south. The Bridge CanyonYellowjacket Canyon-Lower McElmo Creek valley contains conditions of desert lands, and a western desert fauna found nowhere else in Colorado.

The MLSA includes a good representation of local conditions, and contains an assemblage of amphibians and reptiles that is not duplicated elsewhere in Colorado (Table 8). Species only known from the Bridge Canyon-Yellowjacket Canyon system are the Desert spiny lizard (Sceloporus magister), kingsnake (Lampropeltis getulus), and, perhaps, the coachwhip snake (Masticophis flagellum). In addition, the system harbors the rare leopard lizard (Crotaphytus wislizenii) and spotted nightsnake (Hypsiglena torquata), two reptiles that only occur in the desert areas of extreme western Colorado. The uncommon Utah black-headed snake (Tantilla utahensis) and other secretive snake species may also occur in the arid land parts of SW Colorado, but only extensive searches or pit fall trapping will reveal their presence.

Several more widespread desert species also occur in the MLSA: spadefoot toad (Scaphiopus hammondi), Utah tiger salamander (Ambystoma tigrimum utahensis), western whiptail lizard (Cnemidophorus tigris), tree lizard (Urosaurus ornatus), and yellow-headed collared lizard (Crotaphytus collaris auriceps). Although unrecorded on the MLSA, nearby occur the leopard frog (Rana pipiens), short-horned lizard (Phrynosoma douglassi), sagebrush lizard (Sceloporus graciosus), Plateau whiptail lizard (Cnemidophorus velox), milk snake (Lampropeltis triangulum), and wandering garter snake (Thamnophis elegans vagrans). 
We now know that MLSA herpetofauna consists of at least 16 species: 1 salamander, 3 toads, 7 lizards, and 5 snakes (Table 8). Two species of lizards and two or more species of snakes may be added to the fauna with further effort. The occurrence of this rich herpetofauna poses intriguing questions about the limital ranges of several species. The ecological roles and adaptive strategies of Sceloporus magister and Crotaphytus wislizenii at the eastern edges of their ranges are two problems that merit scientific study. The Bridge Canyon system is also an area where habitat separation can be examined in Uta stansburianaUrosaurus ornatus, Sceloporus magister-S. undulatus (possibly also to $S$. graciosus), Cnemidophorus tigris-C. velox, and Crotaphytus collaris-C. wislizenii. The MLSA has high potential for a research natural area for studies of desert reptiles and amphibians, and other aspects of desert ecology.

The establishment of the McElmo Rare Lizard and Snake Area has not resulted in adequate protection for the unique herpetofauna and native vegetation. The habitat in the MLSA is being severely degraded by sheep grazing. The entire area (except solid rock and cliffs) is a maze of sheep trails, and little vegetation remains on the ground. All palatable plant material is heavily grazed. The upper valley (north of the bridge) is the heart of the reserve-- its lowland valley probably once contained viable populations of several species of lizards such as Uta stansburiana and Crotaphytus wislizenii. The bottomland there is now denuded and the slopes are eroded. To the south of the bridge and immediately east of the MLSA is a holding area for sheep. Grazing pressure has probably decreased the reptile populations, and presently is the gravest threat to the biological integrity of the MLSA ecosystem. This problem can be alleviated in several ways. I recommend that the following guidelines be implemented for wise management of this diverse fauna.

1. Grazing permits for the area (MLSA and the rest of Sec. 22) should be withheld.

2. Man-made water holes in and near the MLSA should be eliminated so that sheep will not congregate on these lands. 
3. The MLSA should be fenced in order to keep roaming domestic animals out of the reserve.

Fencing may be expensive, but it appears to be the only means to preserve the biological values of the reserve. Fences should conform to the natural barriers of the reserve for maximal exclusion of sheep and other livestock at the most reasonable investment. One possible placement of fencing to divert sheep into the NE Fork of Bridge Canyon is shown in Figure 17. The gap between the two sides of the bridge should be fenced if the rock spillway does not act as a natural barrier. The southwest part of the MLSA and the north boundary would also need fencing. The west boundary of the reserve is the Utah-Colorado border and is already fenced with steel poles and good wire.

I strongly recommend that more area be added to the McElmo Rare Lizard and Snake Area further northward along Bridge Canyon (north half of Sec. 22). The priorities should be to obtain habitat (1) along the wash and adjacent alluvial bottomland; (2) on canyon sides; and (3) on mesas.

Additions to the MLSA could create a natural area including a substantive portion of the Bridge Canyon drainage. To the SE of the MLSA is a small parcel of land (Sec. 27, NW 1/4, W 1/2) that constitutes the only private land along the main fork of Bridge Canyon. Acquisition of this parcel could significantly enlarge the reserve into the canyon bottomland and improve the location of fencing, i.e. one straight fence could be placed across the south boundary of the reserve. Extension of the reserve northward into the canyon area of Sec. 22 (N $1 / 2$ ), Sec. 15 (E 1/2), and Sec. 10-11 (canyon parts) would provide habitat for the Sceloporus magister and other unique forms.

Presently, the only access by road is from the north, and passes the Holly House and Horseshoe House ruins of the Hovenweep National Monument. National Park Service personnel patrol this road, and their assistance would be useful in controlling unauthorized use of the area. There is potential to develop a mutual agreement with the NPS whereby archeological and natural features of the MLSA and Bridge Canyon area could be visited from an access trail starting at 
Holly House, or to the south. A jeep trail entering the MLSA from the south is now inaccessible due to erosion of the roadbed near Yellowjacket Canyon. This road should be left unimproved.

Preservation of the Bridge Canyon ecosystem will provide a study area that will enable comparisons of productivity, stability, and diversity in natural and man-altered environments. Once grazing is halted, the changes in the flora and fauna may be dramatic. Knowledge of the responses of biota to a release from heavy grazing pressure will be useful for wildlife management decisions in many areas. Bridge Canyon contains a rich and diverse herpetofauna that should be conserved. If well protected, the MLSA will serve as a valuable island of native habitat in the midst of utilized land. The preservation of such an area of high biological diversity will serve as a model for other management units. 


\section{LITERATURE CITED}

Bury, R. B., R. A. Luckenbach, and S. D. Busack. 1977. Effects of off-road vehicles on vertebrates in the California Desert. U.S. Fish and Wildlife Service, Wildlife Research Report, 8:1-23.

Douglas, C. L. 1966. Amphibians and reptiles of Mesa Verde National Park, Colorado. Univ. Kans. Publ., Mus. Nat. Hist., 15:711-744.

Maslin, T. P. 1959. An annotated check list of the amphibians and reptiles of Colorado. Univ. Colo. Studies, 6:1-98.

McCoy, C. J. 1962. Noteworthy amphibians and reptiles from Colorado. Herpetologica, 18(1):60-62.

McCoy, C. J. 1964. The snake Tantilla utahensis Blanchard: an addition to the fauna of Colorado. Herpetologica, 20(2):135-136.

McCoy, C. J. 1966. Life history and Ecology of Cnemidophorus tigris septentrionalis. Diss. Absts. 26(12). 2 pp.

McCoy, C. J. 1967. Natural history notes on Crotaphytus wislizenii (Reptilia: Iguanidae) in Colorado. Amer. Midl. Nat., 77(1):138-146.

Parker, W. S., and E. R. Pianka. 1976. Ecological observations on the leopard lizard (Crotaphytus wislizenii) in different parts of its range. Herpetologica, 32(1):95-114.

Smith, H. M., T. P. Maslin, and R. L. Brown. 1965. Summary of the distribution of the herpetofauna of Colorado. Univ. Colo. Studies, 15:152.

Somners, P. 1974. Preliminary report and literature survey: Dolores Project-Amphibians and Reptile Inventory. Unpubl. photocopy, Fort Lewis College, Durango, Colo. $30 \mathrm{pp}$.

Spencer, A. W. 1974. First record of the kingsnake, Lampropeltis getulus, in Colorado. J. Colo.-Wyo. Acad. Sci., 7(5):79-80.

Tinkle, D. W. 1976. Comparative data on the population ecology of the Desert spiny lizard, Sceloporus magister. Herpetologica, 32(1):1-6. 


\section{LITERATURE CITED (continued)}

Zortman, R. D. 1968. Natural areas in Colorado: their administration by the Bureau of Land Management, MSc Thesis. Colorado State University. 
Table 1. Amphibians and reptiles occuring on the western slope of the Rocky Mountains in Colorado (Smith et al. 1965).

\begin{tabular}{|c|c|}
\hline Common Name & Genus \\
\hline Utah tiger salamander & Ambystoma tigrinum utahensis \\
\hline red-spotted toad & Bufo punctatus (Mesa County and south) \\
\hline western toad & Bufo boreas boreas \\
\hline Rocky Mountain toad & Bufo woodhousei woodhousei \\
\hline bullfrog (introduced) & Rana catesbeiana \\
\hline leopard frog & Rana pipiens \\
\hline chorus frog & Pseudacris triseriata maculata \\
\hline many-lined skink & Eumeces multivirgatus gáigeae \\
\hline short-horned lizard & Phrynosoma douglassi \\
\hline sagebrush lizard & Sceloporus graciosus graciosus \\
\hline eastern fence lizard & Sceloporus undulatus elongatus \\
\hline midget faded rattlesnake & Crotalus viridis concolor \\
\hline milk snake & Lampropeltis triangulum (2 spp.) \\
\hline bullsnake & Pituophis melanoleucus (2 spp.) \\
\hline smooth green snake & Opheodrys vemalis blanchari \\
\hline black rat snake & $\begin{array}{l}\text { Elaphe guttata emoyi } \\
\text { (west central and southeastem Colorado) }\end{array}$ \\
\hline wandering garter snake & Thamnophis elegans vagrans \\
\hline black-headed gartersnake & Thamnophis cyrtopsis \\
\hline
\end{tabular}


Table 2. Amphibians and reptiles occuring principally in the western tier of counties (Moffatt to Montezuma Cos.) in Colorado (see text for sources).

\begin{tabular}{ll}
\hline Common Name & Genus \\
\hline canyon treefrog & Hyla arenicolor \\
western spadefoot toad & Scaphiopus hammondi \\
Great Basin spadefoot toad & Scaphiopus intermontanus \\
painted turtle & Chrysemys picta bellii (isolated population) \\
western whiptail lizard & Cnemidophorus tigris septentrionalis \\
plateau whiptail lizard & Cnemidophorus velox \\
collared lizard & Crotaphytus collaris auriceps \\
leopard lizard & Crotaphytus wislizenii punctatus \\
lesser earless lizard & Holbrooki maculata approximans \\
desert spiny lizard & Sceloporus magister bimacilosus \\
tree lizard & Urosaurus omatus wrighti \\
side-blotched lizard & Uta s. stansburiana \\
yellow-bellied racer & Coluber constrictor mormon \\
Hopi rattlesnake & Crotalus viridis nuntius \\
spotted night snake & Hypsiglena torquata loreala \\
common kingsnake & Lampropeltis getulus \\
coachwhip & Masticophis flagellum piceus \\
striped whipsnake & Masticophis taeniatus taeniatus \\
Utah black-headed snake & Tantilla planiceps utahensis \\
\hline
\end{tabular}


Table 3. Reptiles and amphibians observed on eight line transects (each $1 \mathrm{mi}$. long) in western Montezuma Co., Colorado.

\begin{tabular}{lccclll}
\hline \multicolumn{1}{c}{ Site } & Date & Species & N & \multicolumn{2}{c}{ Composition of species } \\
\hline A. North Fork of Bridge & June 17 & 4 & 9 & 4 & Cnemidophorus tigris & (3Ad:1 Juv) \\
Canyon & $(0900-1100)$ & & & 2 Crotaphytus collaris & (Ad) \\
& & & 1 & Sceloporus undulatus & (Ad) \\
& & & & 1 Uta stansburiana & (Ad)
\end{tabular}

B. NE Fork of Bridge Canyon

C. North boundary of MLSA

D. Bridge Canyon in MLSA

June 17
$(1100-1300)$
June 18
$(0930-1130)$

June 18
$(0920-1130)$

E. Bridge Canyon, 1.5 mi. N of MLSA

F. McClean Basin, 8 mi. NNE of MLSA

G. Hovenweep Canyon, $7 \mathrm{mi}$. NE of MLSA

July 30
$(0900-1100)$

H. Bridge Canyon, 1 mi. S of MLSA

\section{2}
54 C. tigris
5 S. undulatus
3 sceloporus sp.
1 c. collaris
1 U. stansburiana

1 Sceloporus magister

(2Ad:2Juv)

(Ad)

144 Ctigris

$4 \quad 155$ C. tigris

(Juvs)

(4Ad:1Juv)

(Ads)

(1Ad:2Juvs)

(Ad)

(Ad)
July 25

(0900-1200)

August 15

\section{C. tigris \\ 7 S. magister}

122 S. undulatus

(0830-1100)

3

42 C. tigris

1 Sceloporus graciousus

1 c. collaris

$6 \quad 39 \quad 15$ S. undulatus

10 S. magister

6 U. stansburiana

4 C. collaris

3 C. tigris

1 Bufo punctatus 
Table 4. Numbers of perennial plants in transects $10 \times 50 \mathrm{~m}$ at six quadrats

at the McElmo Rare Lizard and Snake Area (MLSA), Colorado.

The heights and average diameters of

\begin{tabular}{|l|l|c|c|c|c|c|c|}
\hline \multicolumn{2}{r}{} & \multicolumn{5}{c}{ Site } \\
\hline & Species & \multicolumn{2}{c}{ Mesa } & \multicolumn{2}{c|}{ Rocky } & \multicolumn{2}{c|}{ Valley } \\
\hline Common Name & Genus & M1 & M2 & R1 & R2 & V1 & V2 \\
\hline black greasewood & Sarcobates vermiculatus & 62 & 0.5 & & & 18 & 100 \\
\hline fourwing saltbrush & Atriplex canescens & 10 & 8 & & 8 & 105 & \\
\hline shadscale saltbrush & Atriplex confortifolia & & & 16 & & & \\
\hline spiny sagebrush & Artemisia spinescens & 1 & & 88 & & & \\
\hline big sagebrush & Artemisia tridentata & & 25 & & 6 & & \\
\hline winterfat & Eurotia lanata & & 17 & & 41 & & \\
\hline & Cowania sp. & & 10 & 6 & 1 & & \\
\hline Mormon tea & Ephedra virdis & & 6 & 1 & & & \\
\hline rabbitbrush & Chrysothamnus sp. & & & & 25 & & \\
\hline spiny hopsage & Grayia spinosa & & 2 & & 1 & & \\
\hline skunkbrush & Rhus trilobata & & & 5 & & & \\
\hline yucca & Yucca sp. & & & -1 & & & \\
\hline prikly pear & Opuntia polyacantha & 7 & & 1 & & 1 & \\
\hline ash & Fraxinus arronala & & & 10 & 2 & & \\
\hline mountain mahogeny & Cercocarpus sp. & & & 15 & & & \\
\hline Oneseed juniper & Juniperus monosperma & & 2.5 & 12 & 6 & & \\
\hline
\end{tabular}


Table 5. Reptiles found on systematic searches of six quadrats (2ha each) at the McElmo Rare Lizard and Snake Area
Colorado, June-July 1977.

\begin{tabular}{|c|c|c|c|c|c|c|c|}
\hline \multirow{3}{*}{$\frac{\text { Site }}{\text { Mesa (M1) }}$} & \multirow[b]{2}{*}{ Date } & \multirow{2}{*}{$\begin{array}{c}\text { Man-hrs } \\
\text { Searching }\end{array}$} & \multirow[b]{2}{*}{ Species } & \multicolumn{3}{|c|}{ Number } & \multirow{2}{*}{ Remarks } \\
\hline & & & & Total & Caught & Observed & \\
\hline & June 16 & 6 & 1 & 5 & 0 & 5 & 5 Cnemidophorus tigris (3 Ad:2 SubAd) \\
\hline Mesa (M2) & July 25 & 4 & 3 & 11 & 2 & 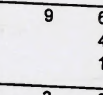 & $\begin{array}{l}6 \text { C. tigris (Ads) } \\
4 \text { Uta stansburiana (1Ad:3Juvs) } \\
1 \text { Crotaphytus wislizenii (Ad) } \\
9 \text { U. stansburiana (Adc) }\end{array}$ \\
\hline Rocky Slope (R1) & June 17-18 & 9 & 5 & 15 & 12 & 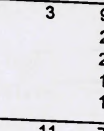 & $\begin{array}{l}9 \text { U. stansburiana (Ads) } \\
2 \text { Urosaurus ornatus (ads) } \\
2 \text { Sceloporus undulatus (Ads) } \\
1 \text { C. tigris (Ad) } \\
1 \text { Crotaphytus wislizenii (Ad) } \\
7 \text { Crotaphytus collaris (Add }\end{array}$ \\
\hline Rocky Slope (R2) & July 31 & 3.5 & 5 & 25 & 14 & 4 & 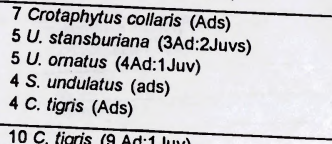 \\
\hline Valley (V1) & June 16 & 7 & 2 & 11 & 2 & $=$ & $\begin{array}{l}10 \text { C. tigris (9 Ad:1Juv) } \\
1 \text { c. wislizenii (Ad) } \\
9 \text { C. tigris (7 Ad.2luv) }\end{array}$ \\
\hline Valley (V2) & July 22 & 5.5 & 2 & 10 & 5 & 5 & $\begin{array}{l}9 \text { C. tigris (7 Ad:2Juv) } \\
1 \text { U. stansburiana }(\mathrm{J})\end{array}$ \\
\hline
\end{tabular}


Table 6. Herpetofauna sampled in ten pit fall traps in or immediately adjacent to the McEImo Rare Lizard and Snake Area, Colorado, July-August 1977.

\begin{tabular}{|c|c|c|c|c|c|}
\hline Date & $\begin{array}{l}\text { Days since } \\
\text { last check }\end{array}$ & Species & $\mathrm{N}$ & C. tigris & Other species \\
\hline July 21 & 1 & 0 & 0 & & \\
\hline July 24 & 3 & 2 & 3 & 2 (1Ad:1Juv) & 1 Sceloporus magister \\
\hline July 25 & 1 & 1 & 1 & 1 (Ad) & \\
\hline July 27 & 2 & 3 & 5 & 2 (Ads) & $\begin{array}{l}1 \text { S. magister (Ad) } \\
2 \text { Sceloporus undulatus (Ad) }\end{array}$ \\
\hline July 28 & 1 & 1 & 2 & 2 (Ads) & \\
\hline August 01 & 4 & 2 & 13 & 12 (11Ad:1Juv) & 1s. undulatus (Ad) \\
\hline August 04 & 3 & 2 & 8 & 7 (Ads) & 1 Bufo woohousei (Ad) \\
\hline August 14 & 10 & 3 & 17 & 13 (10Ad:3Juv) & $\begin{array}{l}2 \text { S. magister (Ads) } \\
2 \text { S. undulatus (Ads) }\end{array}$ \\
\hline August 17 & 3 & 3 & 4 & 2 (Ads) & $\begin{array}{l}1 \text { Scaphiopus hammondi (Ad) } \\
1 \text { Ambystoma tigrinum (Juv) }\end{array}$ \\
\hline August 20-21 & 3-4 & 3 & 7 & 5 (3Ad:2Juv) & $\begin{array}{l}\text { 15. magister (Ad) } \\
\text { is. undulatus (Ad) }\end{array}$ \\
\hline
\end{tabular}


Table 7. Comparison of four different methods of obtaining amphibians and retiles. Data from work at MLSA, June-August, 1977.

\begin{tabular}{|c|c|c|c|c|}
\hline Method & $\begin{array}{c}\text { Number of Individuals } \\
\text { Sighted or Taken }\end{array}$ & Species & Man-hrs & Highlights \\
\hline Opportunistic Surveys & 220 & 8 & many & $\begin{array}{l}1 \text { Pituophis; } \\
\text { new locality records }\end{array}$ \\
\hline Line Transects & 98 & 6 & 24 & $\begin{array}{l}1 \text { Bufo punctatus } \\
1 \text { Sceloporus gracious }\end{array}$ \\
\hline Quadrats & 77 & 6 & 35 & $\begin{array}{l}3 \text { Crotaphytus wislizenii } \\
\text { Urosaurus ornatus }\end{array}$ \\
\hline Pit Fall Traps & 455 & 6 & low & $\begin{array}{l}1 \text { Scaphiopus hammondi } \\
1 \text { Ambystoma tigrinum } \\
1 \text { Bufo woodhousei }\end{array}$ \\
\hline
\end{tabular}


Table 8. Amphibians and reptiles of the McElmo Rare Lizard and Snake Area.

\begin{tabular}{|c|c|c|c|}
\hline Species & $\begin{array}{c}\text { Present } \\
\text { (This study) }\end{array}$ & $\begin{array}{c}\text { Listed by } \\
\text { Zortman (1968) } \\
\end{array}$ & Comments \\
\hline Amphibians & & & \\
\hline Ambystoma tigrinum & $x$ & & First record for MLSA \\
\hline Scaphiopus hammondi & $x$ & $x$ & \\
\hline $\begin{array}{l}\text { Bufo punctatus } \\
\text { Bufo woodhousei } \\
\text { Rana pipiens }\end{array}$ & $\begin{array}{l}x \\
x\end{array}$ & $\begin{array}{l}x \\
x \\
x\end{array}$ & $\begin{array}{l}\text { Probably absent due to lack } \\
\text { of standing water }\end{array}$ \\
\hline
\end{tabular}

$\begin{array}{lll}\begin{array}{l}\text { Cnemidophorus tigris } \\ \text { Cnemidophorus velox }\end{array} & \mathrm{X} & \mathrm{X} \\ & ? & \\ \text { Crotaphytus wislizenii } & \mathrm{X} & \mathrm{X} \\ \text { Crotaphytus collaris } & \mathrm{X} & \mathrm{X} \\ \text { Sceloporus graciosus } & & \mathrm{X} \\ \text { Sceloporus magister } & \mathrm{X} & \mathrm{X} \\ \text { Sceloporus undulatus } & \mathrm{X} & \mathrm{X} \\ \text { Urosaurus ornatus } & \mathrm{X} & \mathrm{X} \\ \text { Uta stansburiana } & \mathrm{X} & \mathrm{X} \\ \text { Phymosoma douglassl } & ? & \\ \text { Holbrookia maculata } & & \end{array}$

At Yellowjacket Canyon; possibly present at MLSA

$x$

$x$

$X \quad$ Probably absent

$\mathrm{x}$

$x$

$\mathrm{x}$

$\mathrm{X}$

Possibly present

Not known for area 
Table 8. (continued)

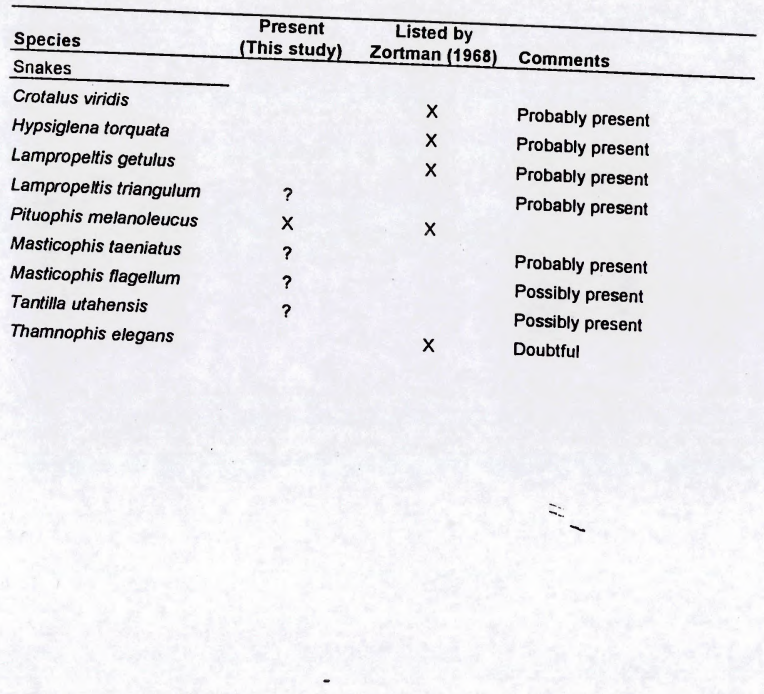




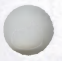

0

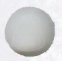




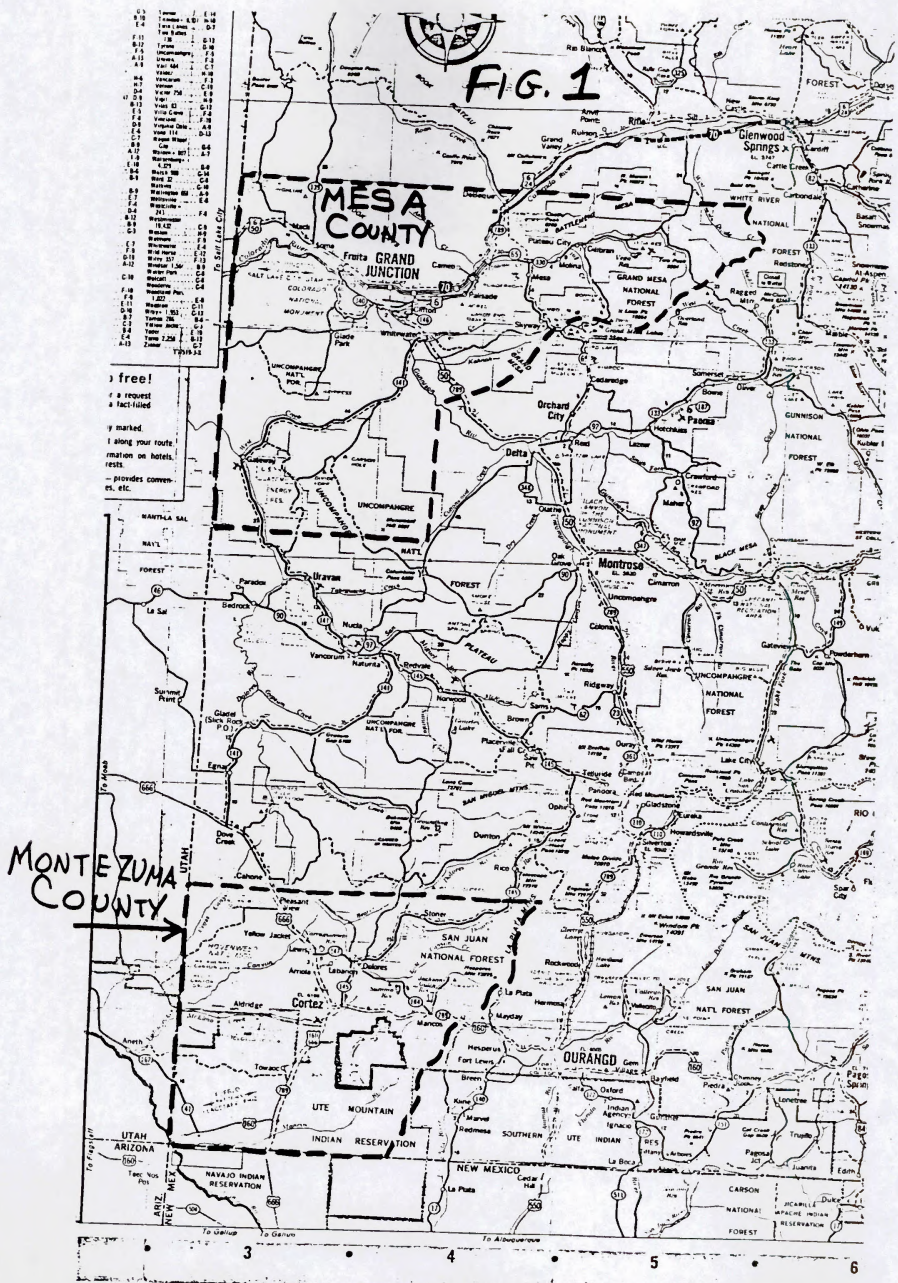


0

0

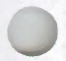



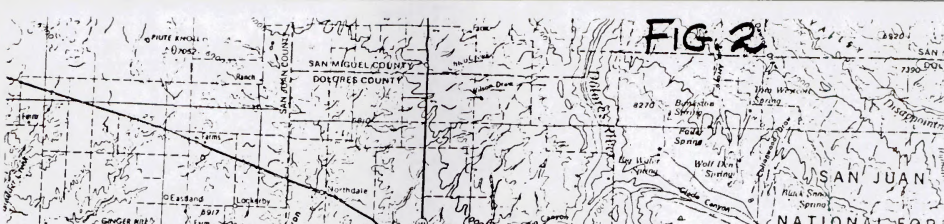

3)

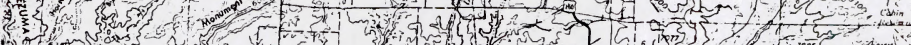

9)

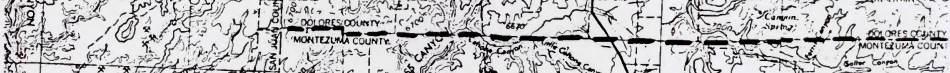
15 an tom (1)

sids

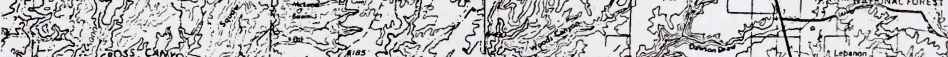
on

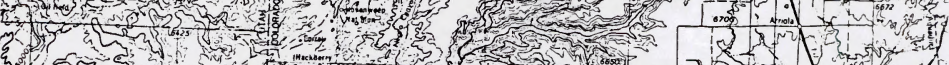
3.5, की 5. Even 17. 2 . 2h

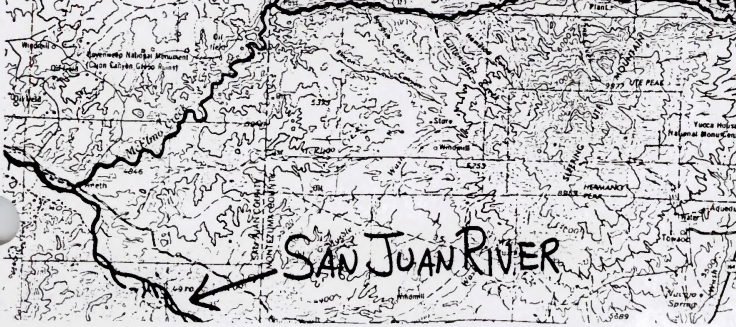


0

0

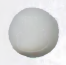




\section{Fig. 3}

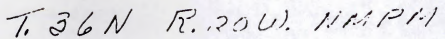

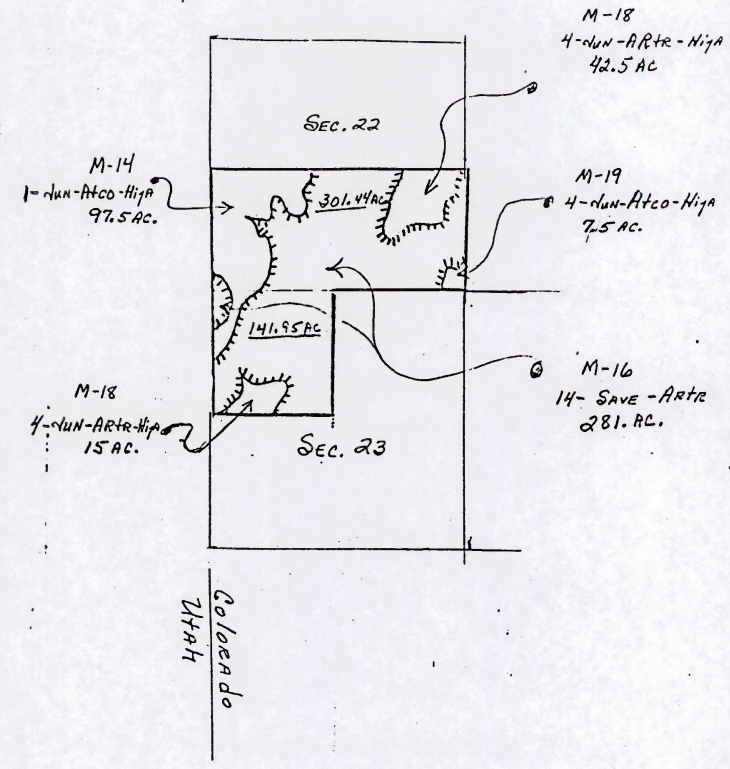


0

0

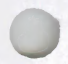




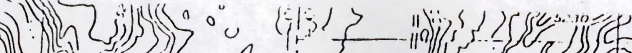

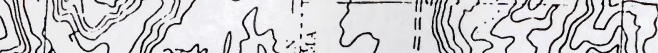

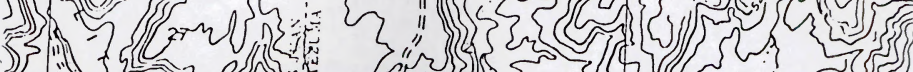
2) in

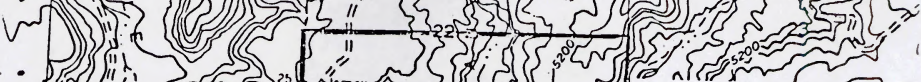
(O) VNo T. 36N., R. 20W., NMPM SE= Colorado - U.S.A.

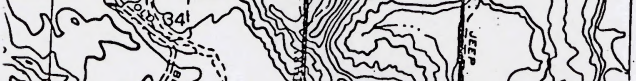

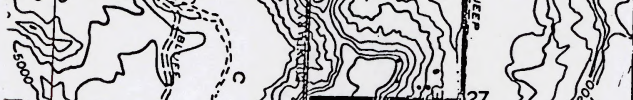

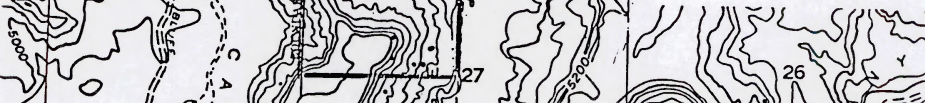
5 . II

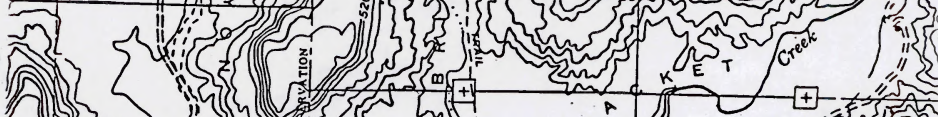

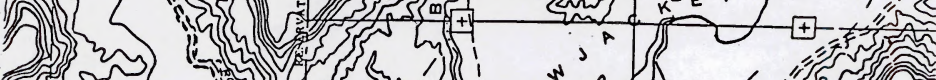
$\left\{\begin{array}{l}3 \\ 3\end{array}\right.$

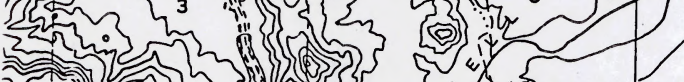
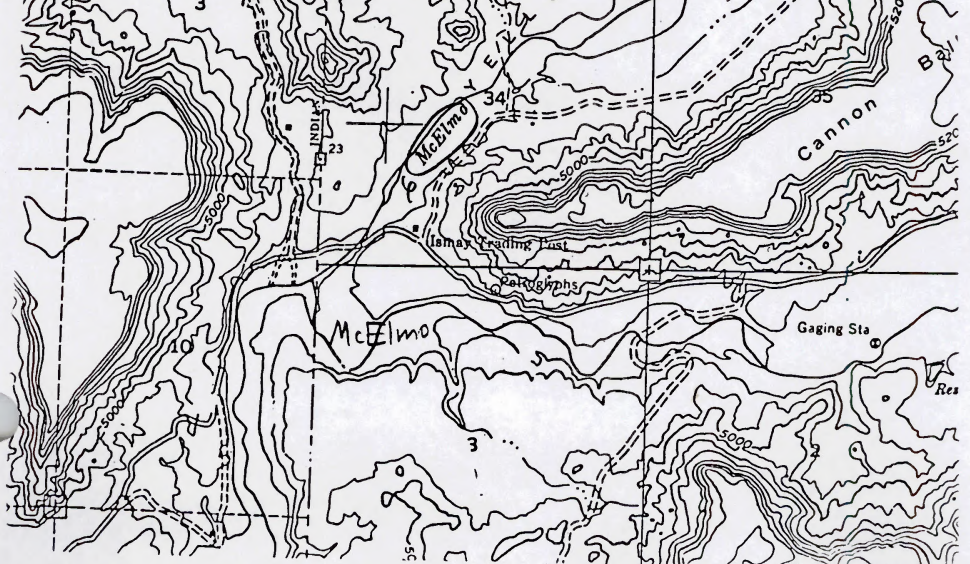


0

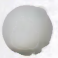




$$
\text { FIG. } 5
$$

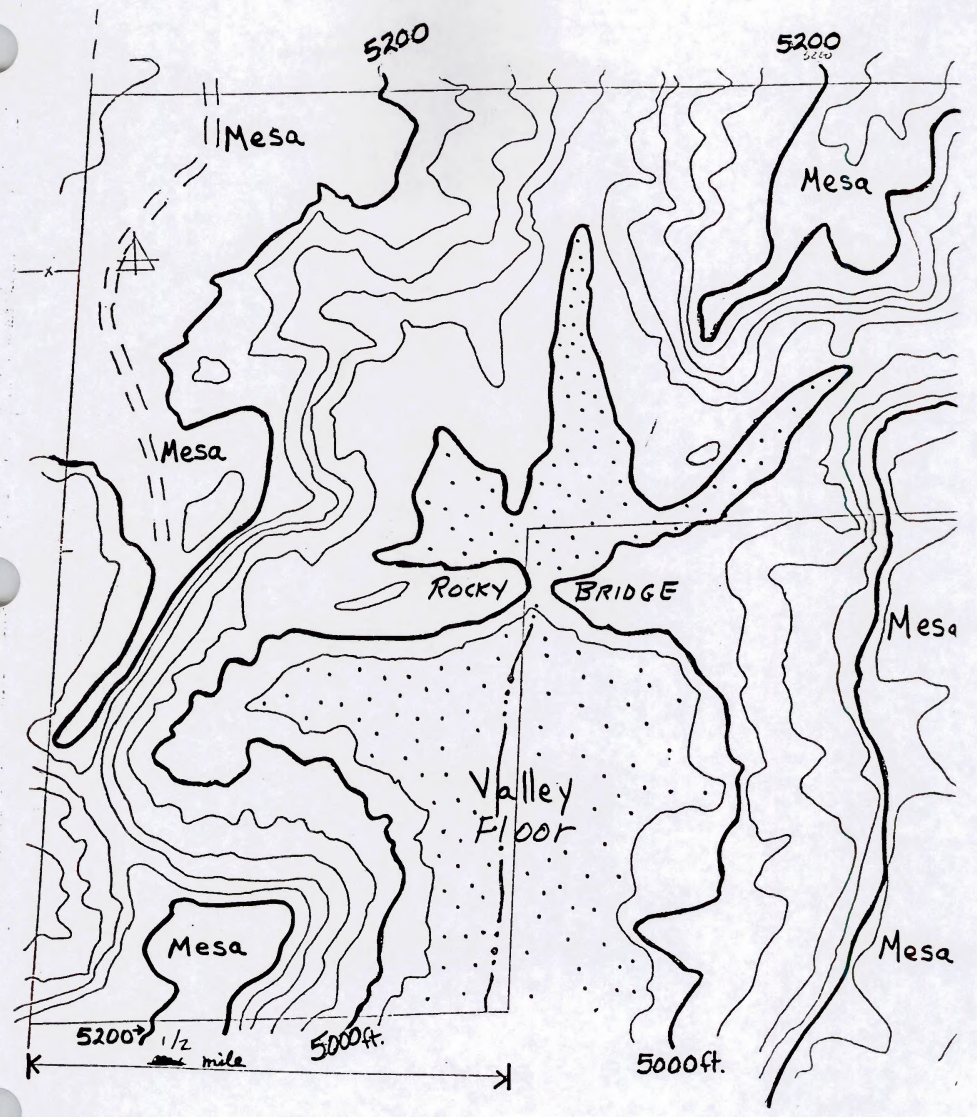




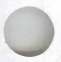

0

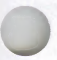




\section{Fig. $6^{.00-11}$ Location of six line transects.}
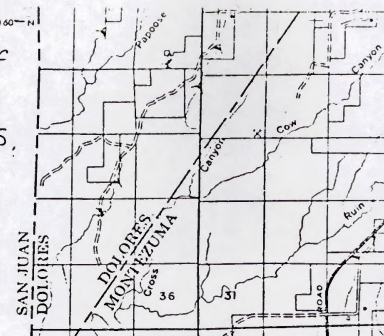

$+$
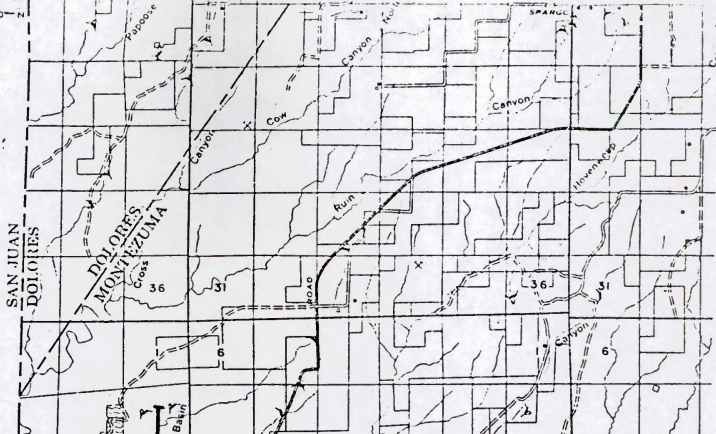

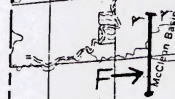
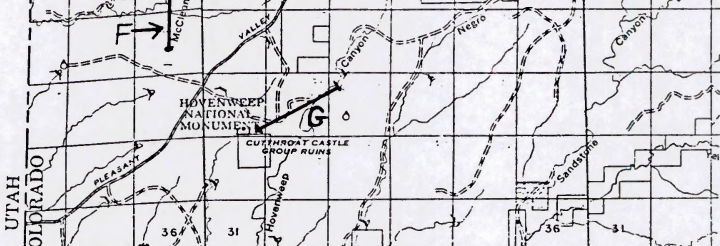
(1)

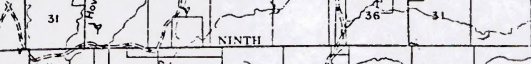

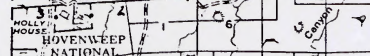
(ais)
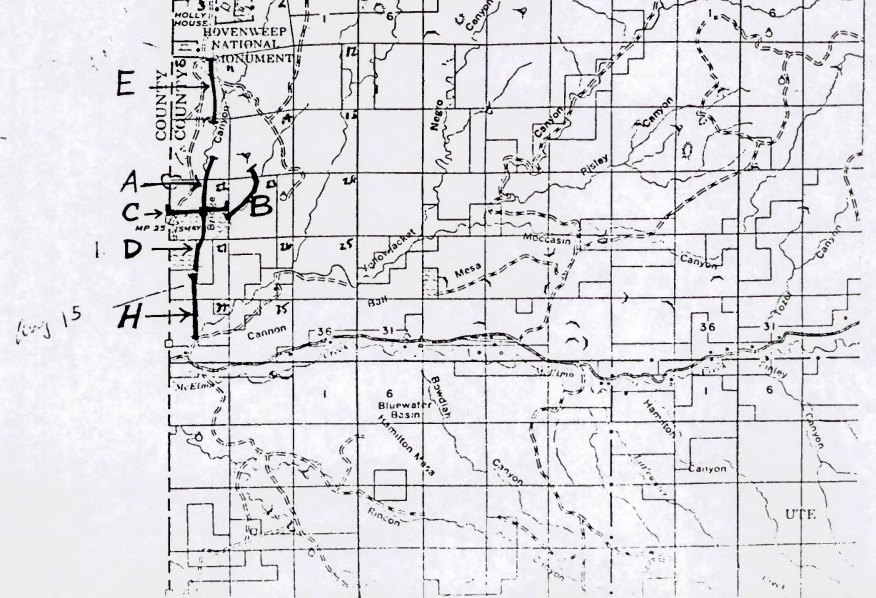
0

o

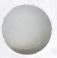




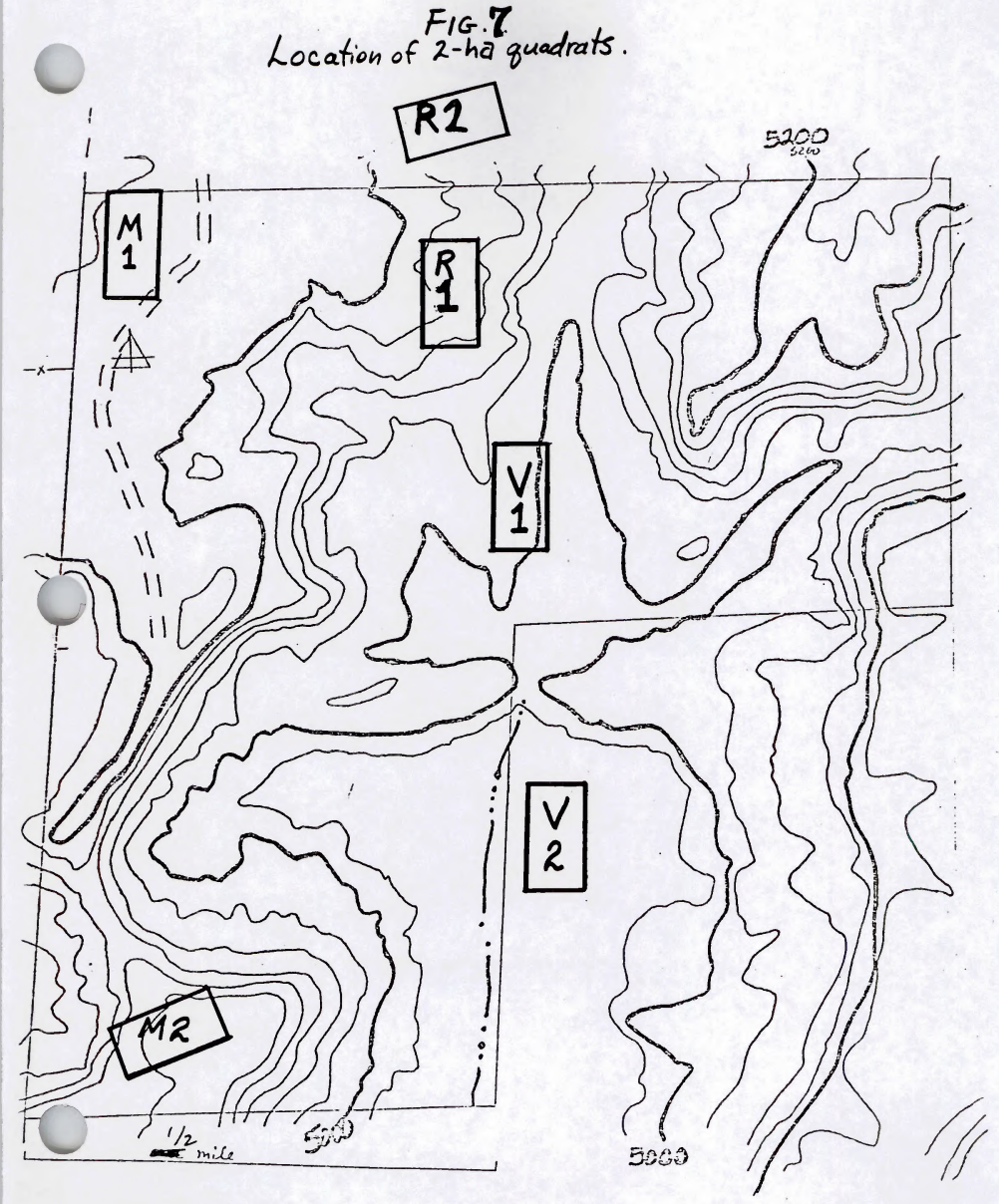


0

0

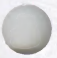




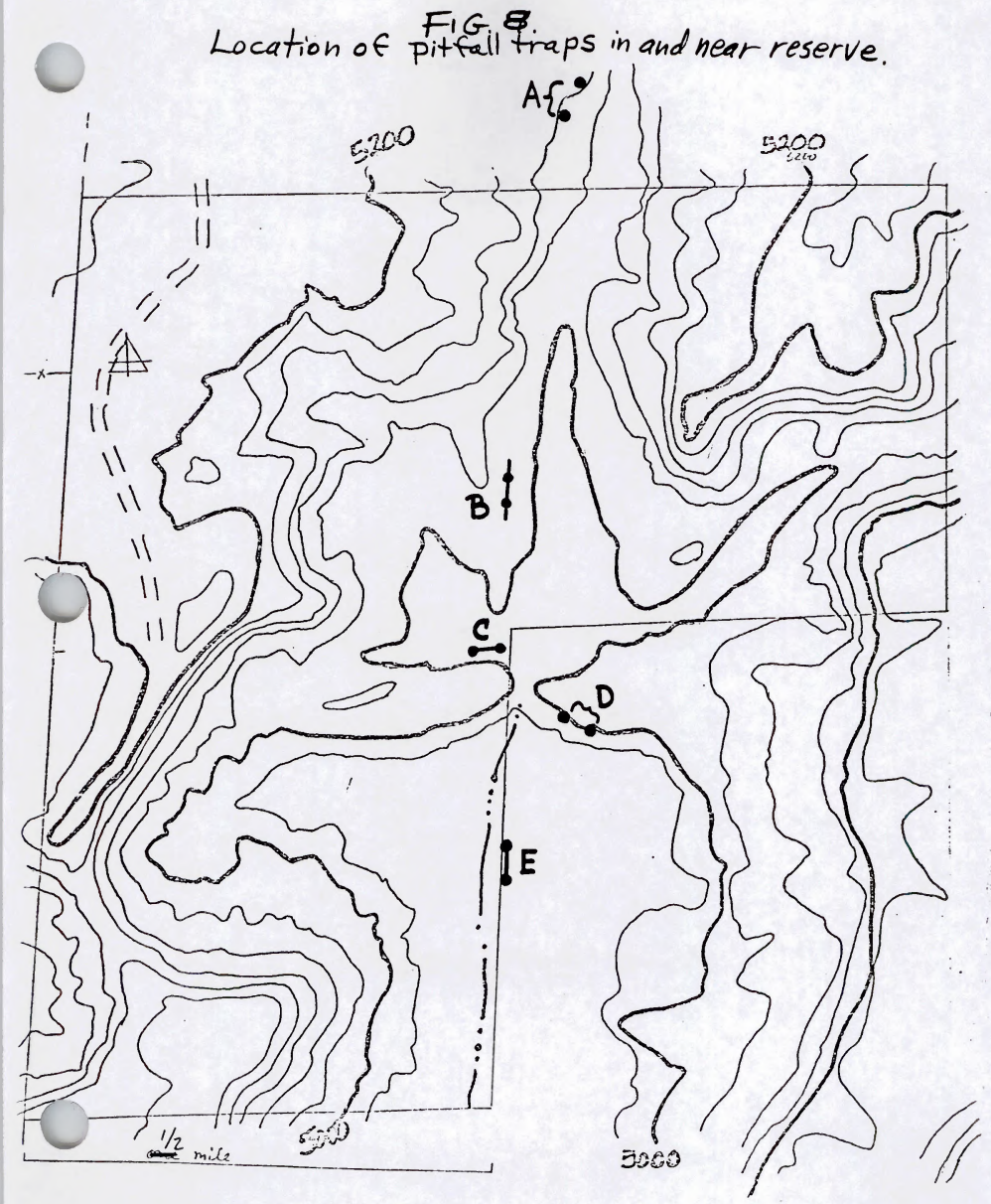




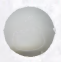

O

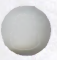




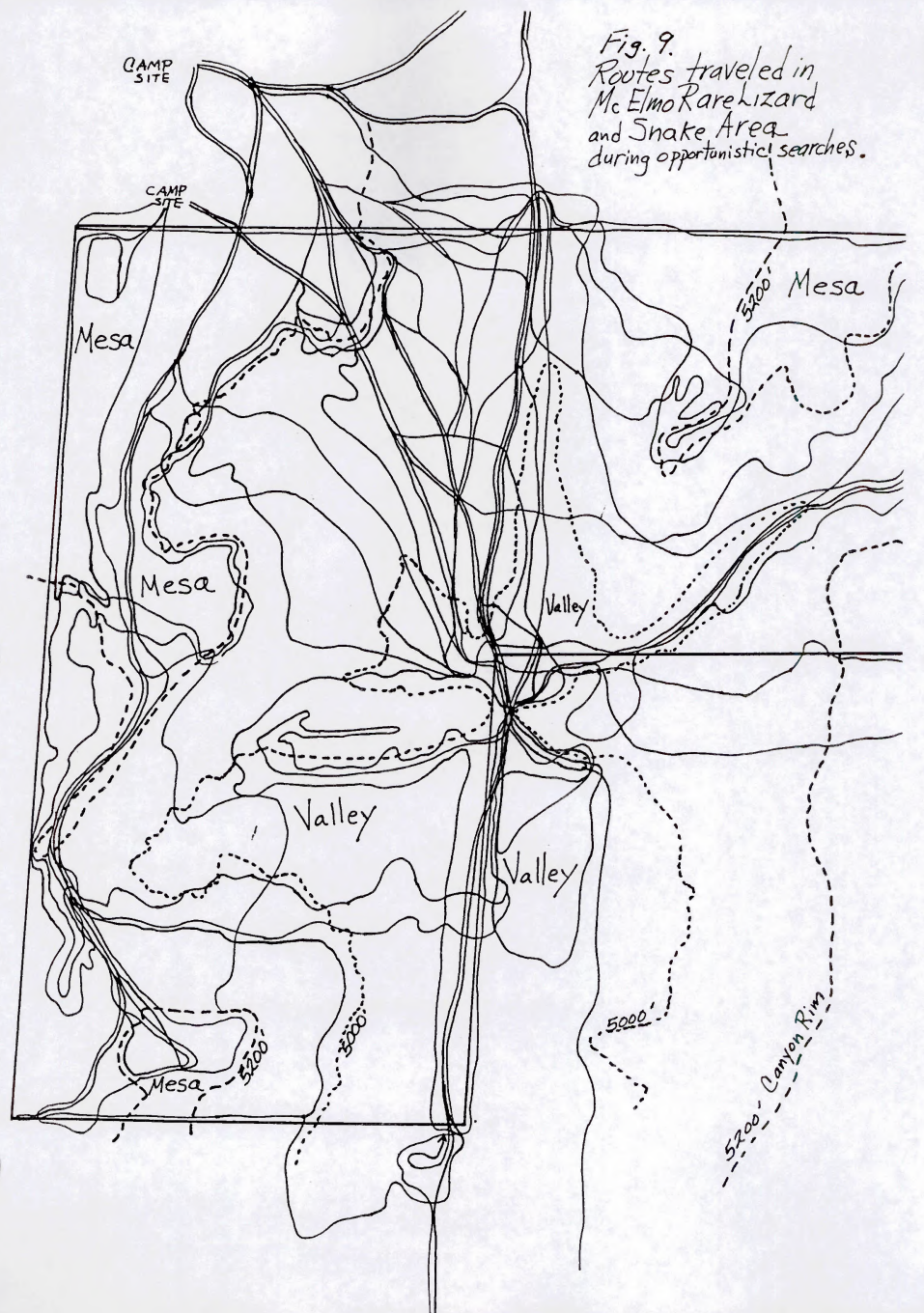


○

0

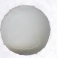




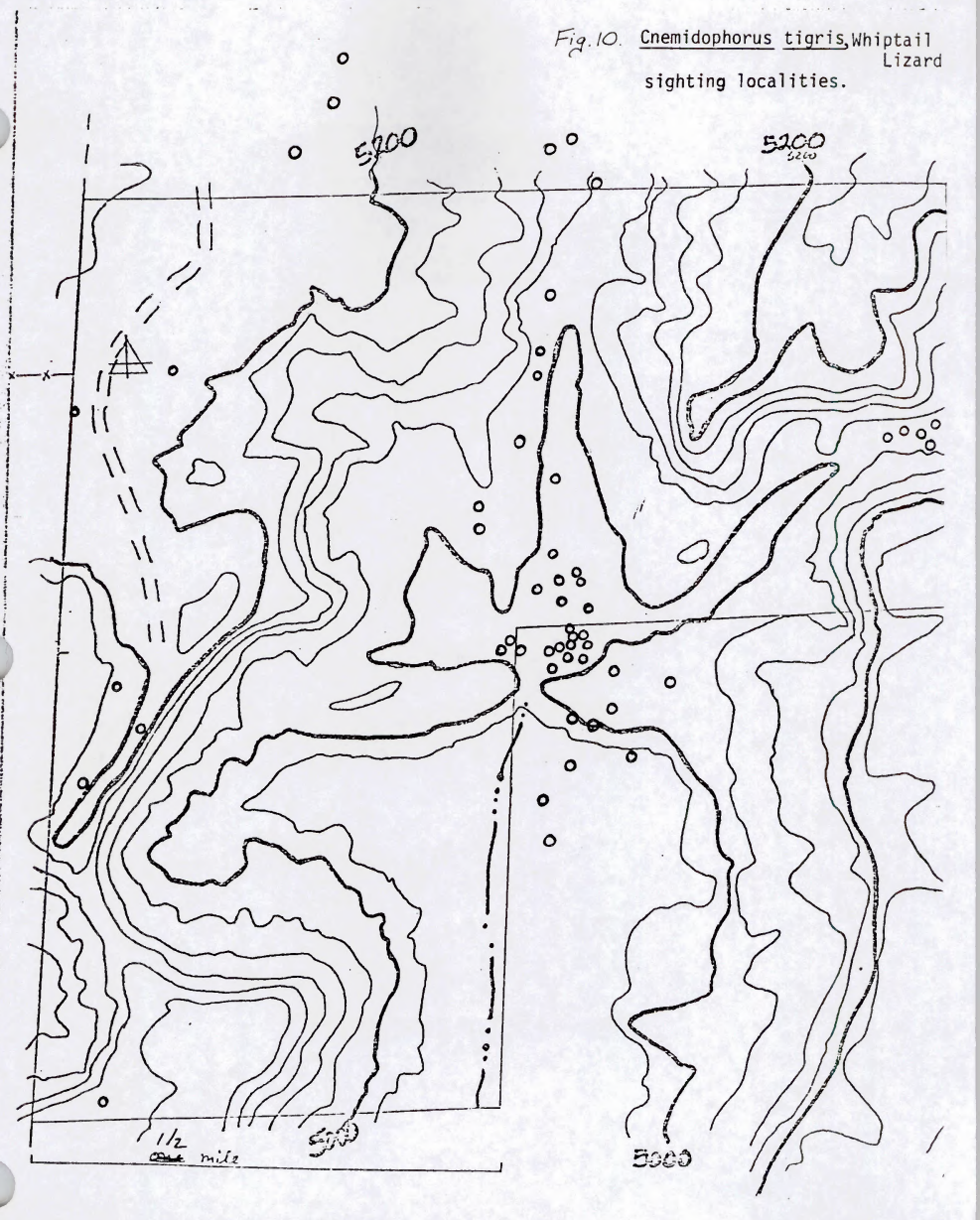


0

0

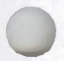




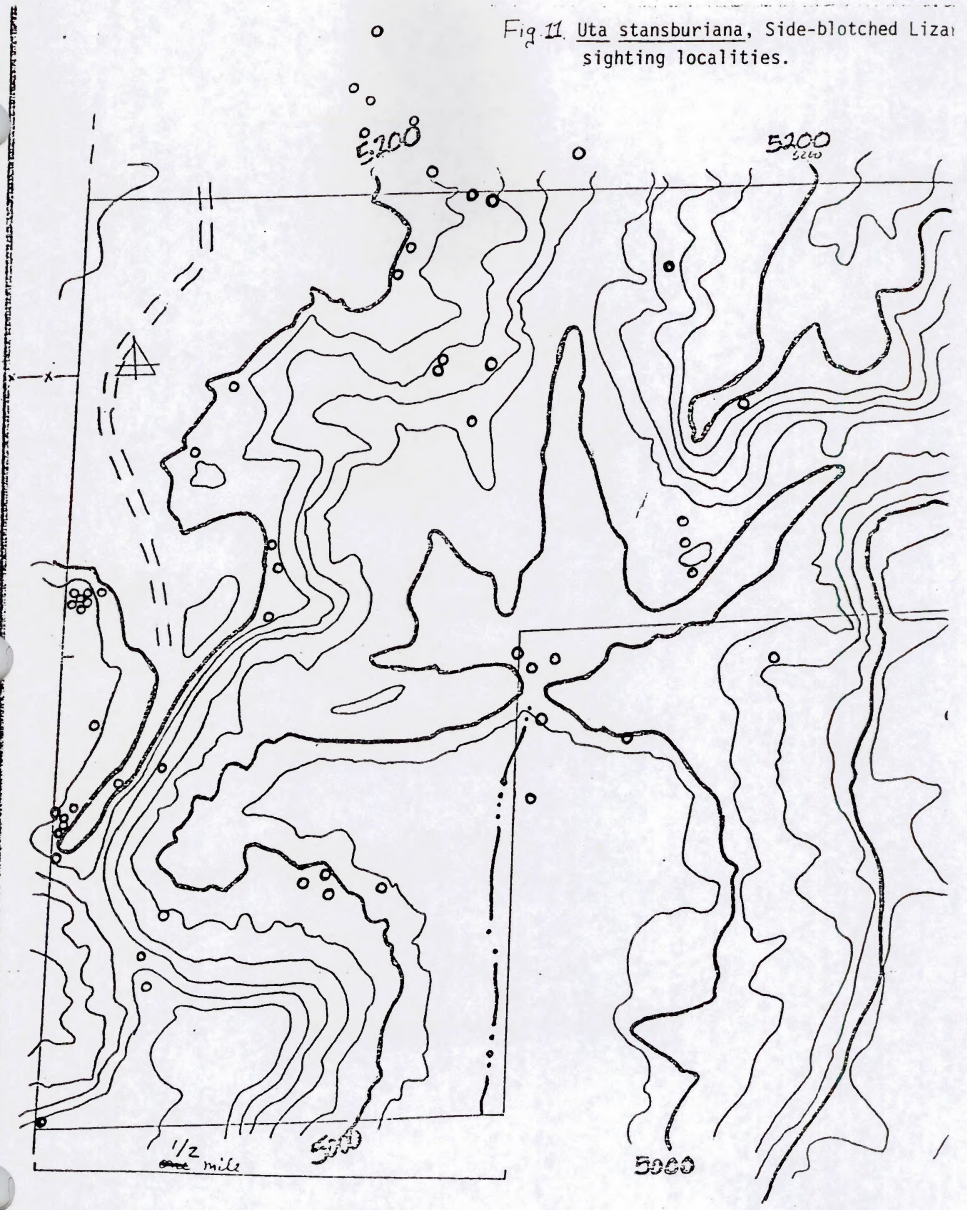


0

0

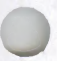


Fig. 12. Urosaurus ornatus, Tree Lizard sighting localities.

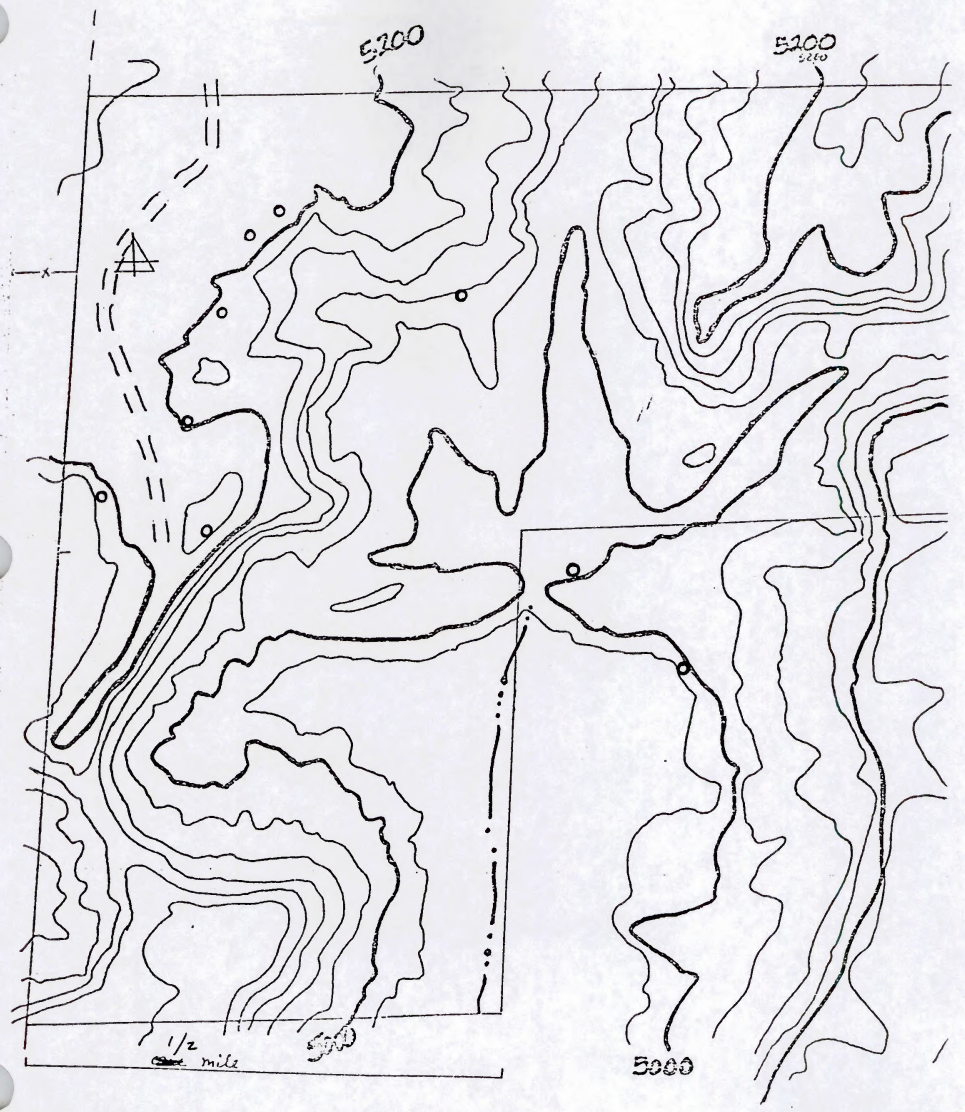


0

0

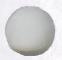


- .

Fig. 13. Sceloporus undulatus, Fence Liz sighting localities.

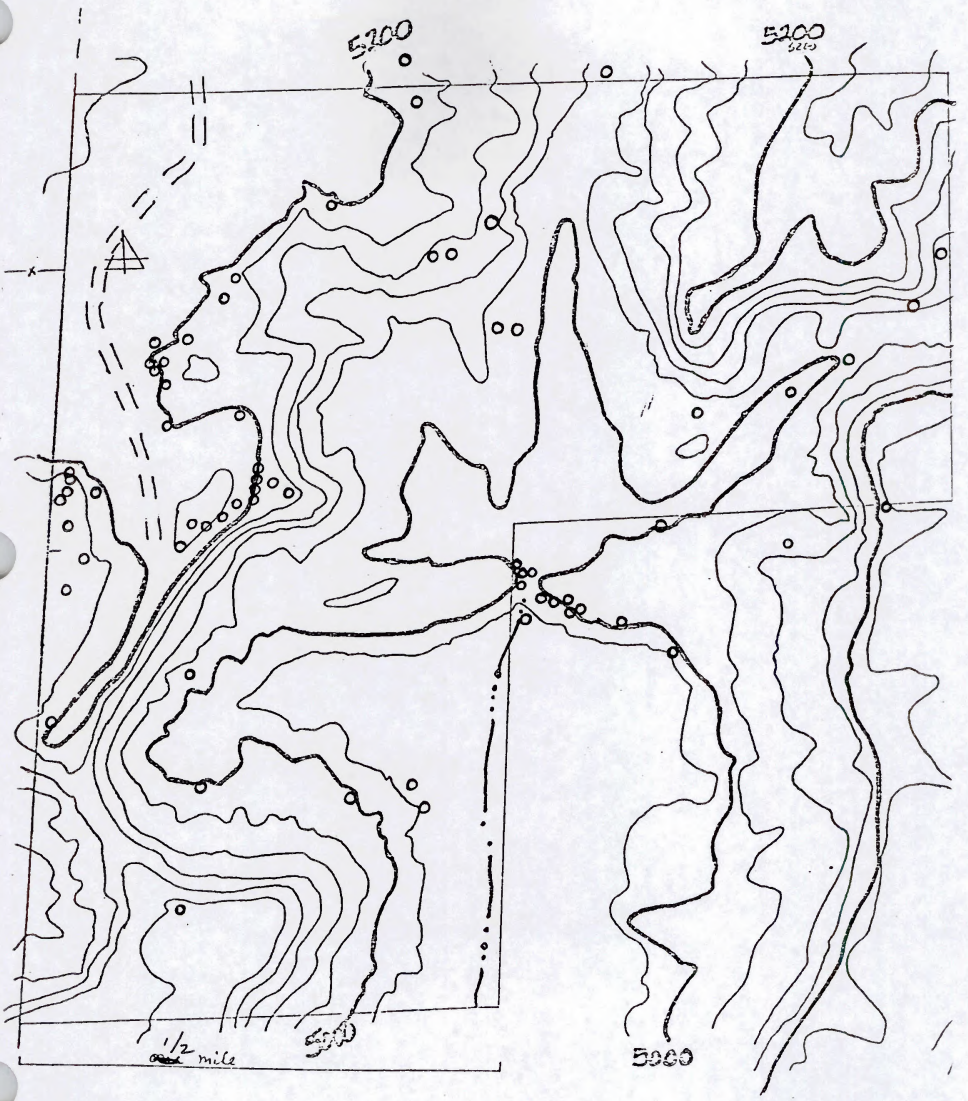


○

0

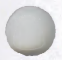


Fig. 14. Sceloporus magister, Desert Spiny Li. sighting localities.

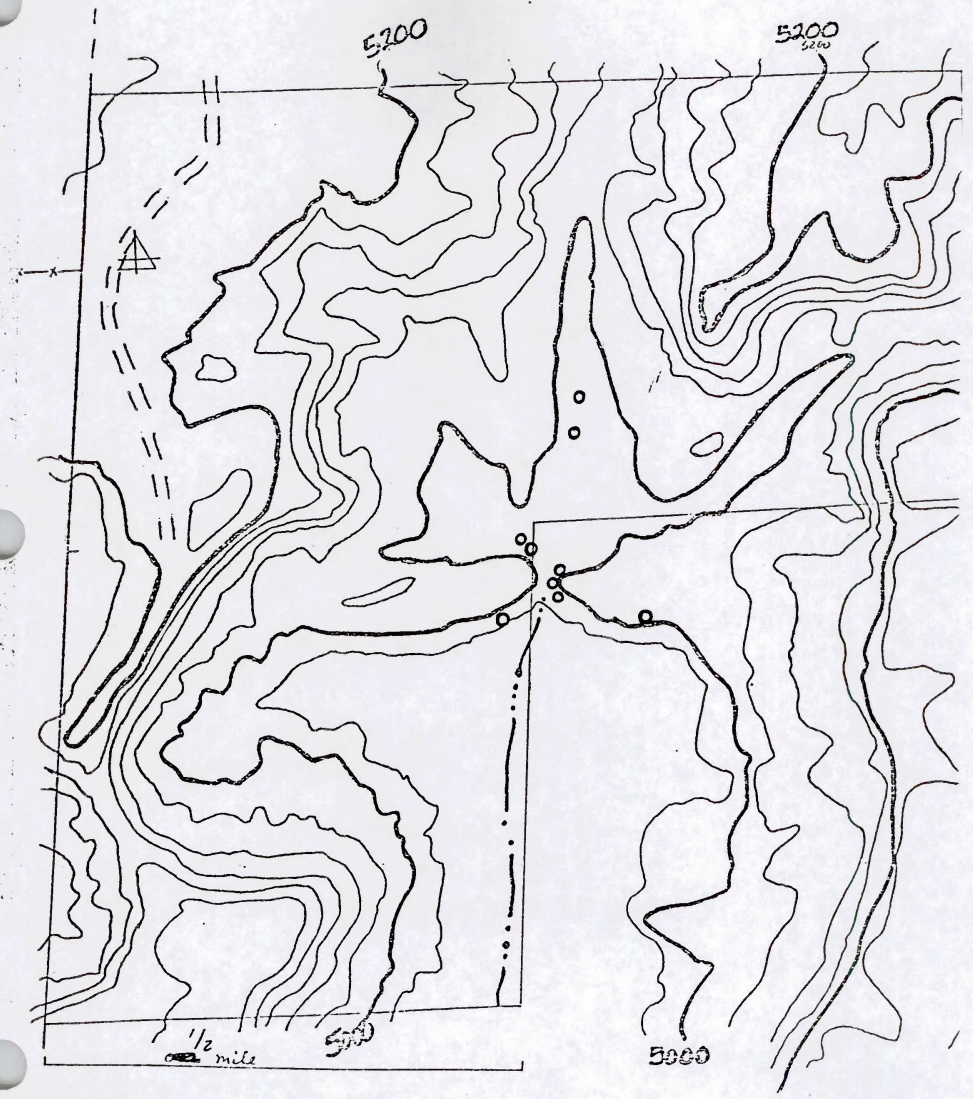


○

0

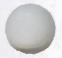




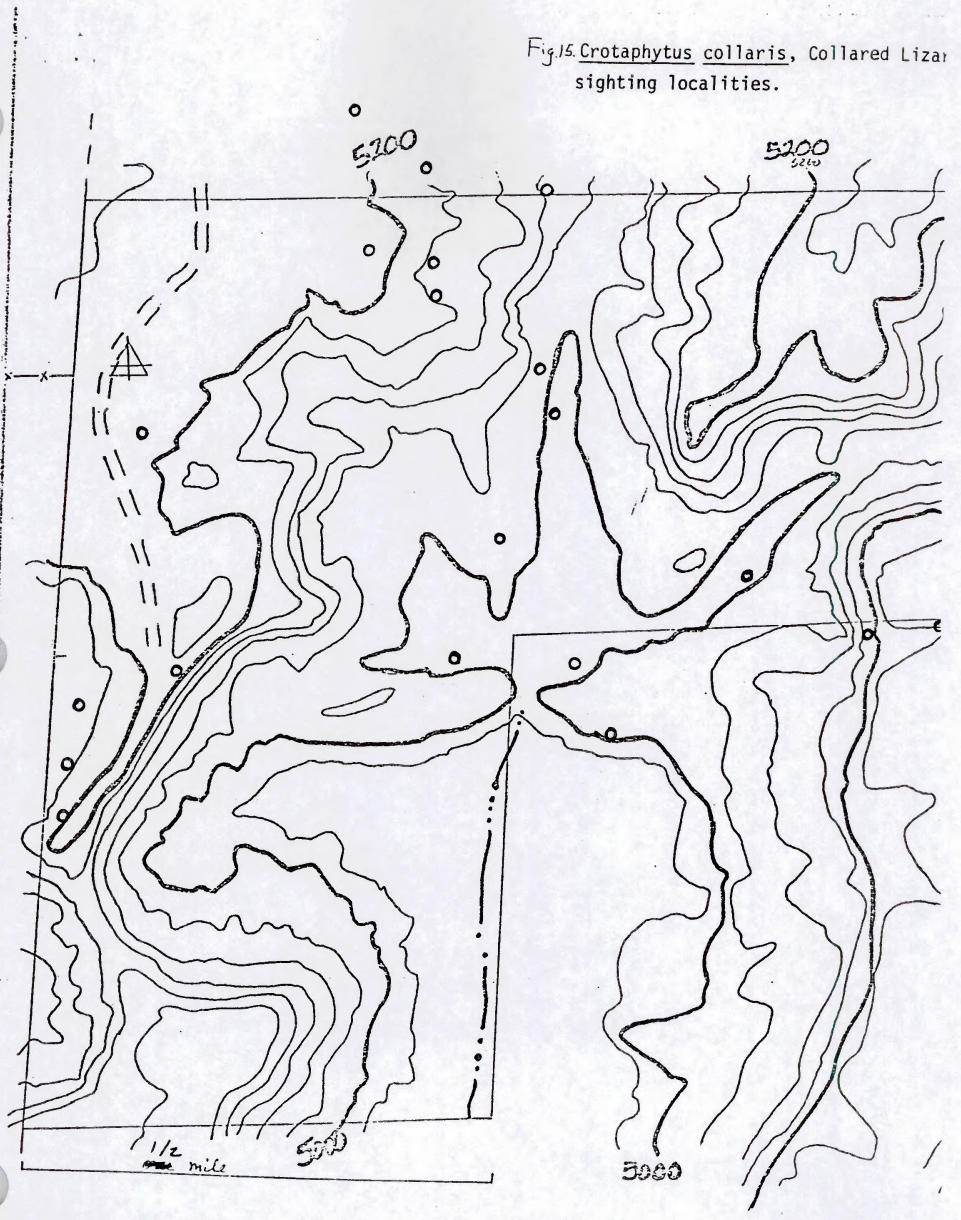


0

0

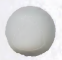


Fig. 16. Crotaphytus wislizenii, Leof Lizard sighting localities.

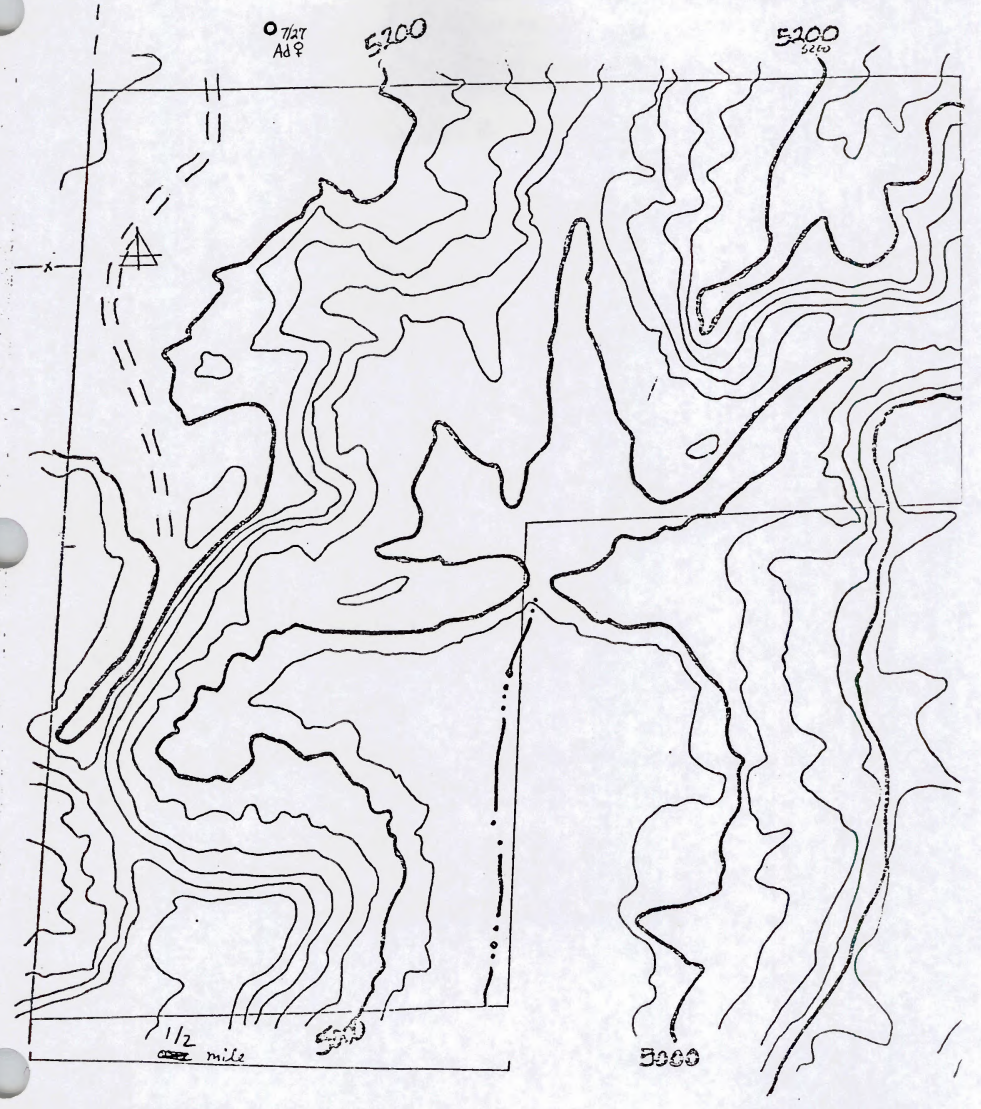




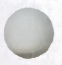

0

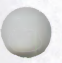




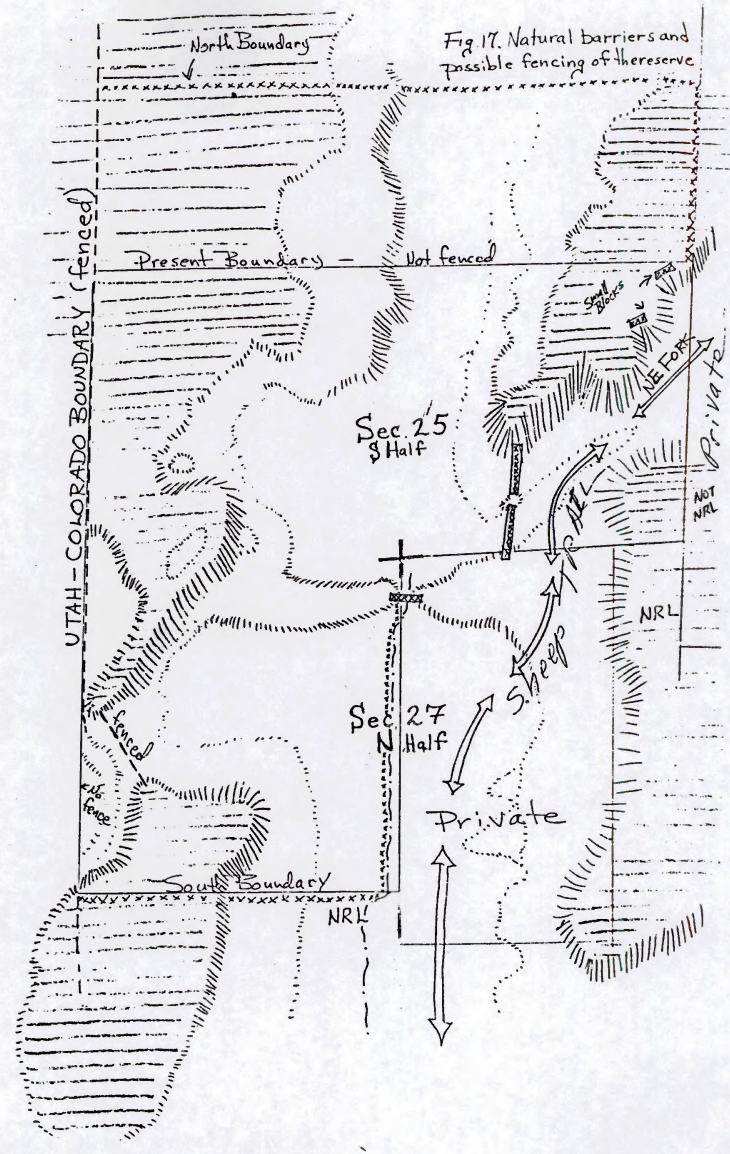


○

0

0 